\title{
J. RZEDOWSKI
}

Colegio de Post-Graduados

Escuela Nacional de Agricultura

Chapingo, Mex.

\section{INDICE DE MATERIAS}

I. INTRODUCCION ............................ 123

A. Objetivos, alcance y plan del presente trabajo .......... 123

B. Riqueza florística de México y sus causas . . . . . . . . . . . . . 124

C. Historia de los estudios de afinidades y orígenes de la flora de México ............................ 124

D. Agradecimientos ........................... 125

1I. ANALISIS FLORISTICOS QUE ABARCAN TODO EL PAIS ......... 125

III. ANALISIS FLORISTICOS REGIONALES ................ 130

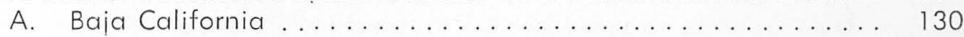

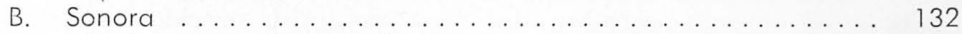

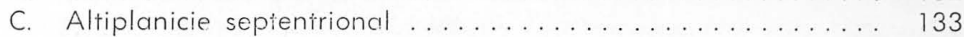

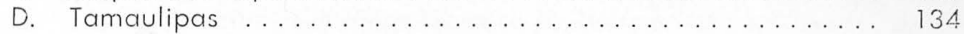

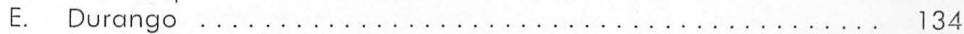

F. San Luis Potosí .......................... 134

G. Islas Tres Marías .......................... 136

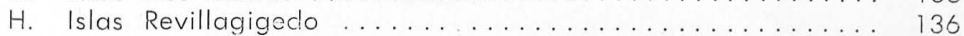

I. Jalisco y Colima ........................... 135

J. Cuenca de México .......................... 137

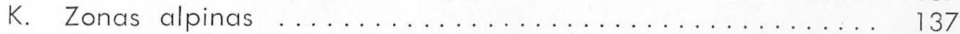

L. Cuenca del Balsas ......................... 138

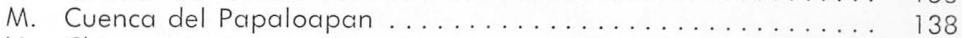

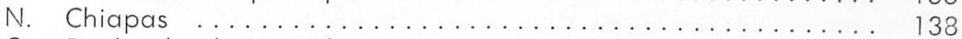

O. Península de Yucatán .................... 140

* Trabajo presentado en los Coloquios sobre el estado actual de los estudios fitogeográficos de
México.

Rzedowski J. 1965. Relaciones geográficas y posibles orígenes de la flora de México. Boletín de la Sociedad Botánica de México 29:121-177. 
IV. ANALISIS DE RELACIONES BOREALES ............... 141

V. ANALISIS DE RELACIONES MERIDIONALES .............. 146

VI. ANALISIS DE RELACIONES CON OTRAS REGIONES .......... 149

A. Relaciones con las Antillas ................... 153

B. Relaciones con Asia ........................ 153

C. Relaciones con Africa ........................ 154

VII. MEXICO COMO CENTRO DE ORIGEN Y DIVERSIFICACION DE

FLORAS ............................ 155

A. Plantas de clima árido ................... 155

B. Plantas de clima templado y frío ................ 158

C. Plantas de clima caliente ..................... 159

VIII. REGIONES FLORISTICAS DE MEXICO ................ 160

A. México en las divisiones fitogeográficas del globo . . . . . . 160

B. Problema del límite entre las regiones holártica y neotropical 161

C. Zonas de vegetación ..................... 162

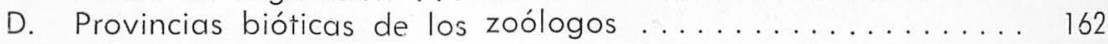

IX. RESUMEN Y CONCLUSIONES ..................... 165

X. SUMMARY AND CONCLUSIONS ................... 168

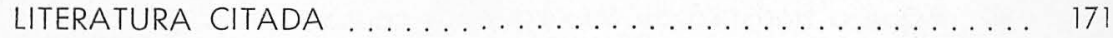




\section{INTRODLCCION}

\section{A. Objetivos, alcance y plan del presente trabajo}

El propósito de esta exposición consiste en una revisión bibliográfica exháustiva de lo que se ha expresado en forma escrita acerca do las relaciones geográficas y de los posibles orígenes de la flora de México. Tomando en cuenta esta finalidad se ha tratado de transcrihir un resumen de la parte más esencial e interesante de cada una de las diferentes contribuciones. Con la mira de lograr una presentación lo mís objetiva posible se han limitado a su expresión mínima las apreciaciones personales del autor; sólo en el capítulo correspondiente al resumen y a las conclusiones aparecen algunas ideas propias, formuladas con la intención primordial de recapitular los conceptos más sobresalientes y de sugerir algunos lineamientos del desarroilo futuro de esta rama de la ciencia.

Resulta evidente que, a pesar del esfuerzo de resumir toda la bibliografía sobre la materia, tienen que haber escapado de la atención del que escribe muchos trabajos en que se tratan problemas de afinidades y orígenes de la flora de México. Tal rez se hayan omitido, inclusive, algunas contribuciones de mayor importancia. El autor agradecerá sinceramente toda clase de observaciones e indicaciones a este respecto, a fin de publicar las referencias faltantes en un suplemento, pues la idea es de ofrecer a los estudiosos de la fitogeografía de México un cuadro completo de lo usta ahora conocido.

Esta revisión bibliográfica está restringida a problemas ligados con las relaciones geográficas y los orígenes de la flora de México, tratando de eliminar los trabajos o las discusiones dedicadas íntegramente a las relaciones geográficas de los tipos de vegetación, a las relaciones ecológicas, a los problemas de distribución de plantas aisladas y a los problemas paleobotánicos o paleoecológicos, algunos de los cuales sor el tema de otras ponencias de este coloquio. Es obvio, por otra parte, que todos estos aspectos están tan íntimamente ligados entre sí. que muchas veces resulta difícil tratarlos en forma enteramente independiente y abundan en la literatura las referencias enfocadas simultáneamente desde varios puntos de vista. por ejemplo el florístico y el ecológico.

El plan que se ha adoptado para la exposición del conjunto es necesariamente arbitrario y adolece de inconvenientes. Se optó por discutir primero las contribuciones relativas al país entero, luego las correspondientes a las diferentes regiones del mismo, en seguida los trabajos en que se discuten las afinidades borcales de la flora, a continuación las meridionales y las existentes con algunas otras regiones del mundo; posteriormente lo relativo a México como centro de origen y de dispers:ón de floras, seguido de la división del país en regiones florísticas, para terminar con el resumen y las conclusiones. El problema principal estriba en el hecho de que la mayor parte de los trabajos encontrados en la literatura se refieren a más de un tópico y en este tipo de arreglo es necesario, a menudo, mencionar'os más de ura rez. Se ha considerado, sin embargo, que la forma de exposición adoptada resulta mucho más ilustrativa y menos monótona que una enumeración por orden cronoló. gico. 


\section{B. Riqueza floristica de México y sus causas}

No se conoce ni siquiera aproximadamente el número de especies que intervienen en la composición de la flora de México. Kotschy, en 1852, intentó la primera re. copilación y obtuvo la cifra de 6642 especies de fanerógamas. La monografía de Hemsley (1879-1888) arroja un número de cerca de 8000 plantas vasculares para e] sur de México y más de 3000 para el norte, que son las dos partes en que ha divi. dido el país. Standley (1920-1926) en su revisión crítica de los árboles y arbustos reconoce 6784 especies, y en general se considera que debe existir un número aproximadamente igual de plantas herbáceas, lo que representaría un total de 13000 a 14000 especies, número susceptible de aumento considerable, dado el aún escaso co. nocimiento de algunos grupos de plantas y de la flora de algunas regiones del país.

A la luz de estos datos Wulff (1937), en su ensayo de dividir el mundo en regiones fitogeográficas a base de la distribución numérica de las especies, incluye el sur de México en la categoría de las zonas florísticamente más ricas del gloho (con más de 7000 especies), mientras que el norte lo sitúa en la categoría siguiente (entre 3000 y 7000 especies).

Varios autores (por ejemplo Standley, op. cit.: 1-3; Sharp [en prensa]) coinciden en sus aseveraciones que el factor principal de la riqueza florística de México reside en su gran variedad de condiciones fisiográficas y climáticas. A ello debe agregarse: lo. que el territorio de la República ha sido sujeto a intensas migraciones de plantas (Sharp, 1953: 378; Dressler, 1954: 81; Martin y Harrell, 1957; y otros) particularmente en los sentidos N-S y S-N; 2o. que México es considerado como centro importante de evolución de floras (véase cap. 7); y 3o. que en la composición de su flora intervienen elementos de procedencia muy diversa, puesto que el territorio del país se halla en la zona limítrofe entre los reinos florísticos holá:tico y neotropical (véase cap. 8, inciso C).

\section{Historia de los estudios de afinidades y orígenes de la flora de México}

La fitogeografía dista mucho de ser una rama científica independiente y aún hoy en día son raras las personas que se dedican exclusiva o principalmente a esta actividad. Los estudios de relaciones florísticas y orígenes de las floras están íntimamente ligados con los conocimientos de la flora y de la vegetación, pues sin los últimos no existe hase para la realización de los primeros.

La rnayor parte de las contribuciones en este campo, referentes a México, se deben a taxónomos y ecólogos o fitosociólogos y consisten comúnmente de capítulos o breves discusiones anexas a floras o estudios de la vegetación; existen algunas discusiones derivadas de revisiones taxonómicas de ciertos grupos, y relativamente pocos trabajos dedicados exclusivamente al problema.

Pueden distinguirse claramente dos períodos de relativo auge en este tipo de estudios sobre México: uno en las últimas tres décadas del siglo pasado y otro a partir de 1945 a la fecha. Ambos períodos coinciden con épocas en que la biogeografía ha alcanzado fases máximas de su desarrollo en escala mundial, pero además el pri- 
mero es contemporáneo de una situación en que el conocimiento de la flora de México y de sus regiones vecinas ha llegado a un estado suficientemente avanzado para hacer posible la realización de análisis profundo, y el segundo es hasta cierto punto el corolario de una intensificación sin precedente de los estudios sobre la vegetación de diferentes regiones del país.

El exponente máximo del primer período es indudablemente Hemsley. Como iniciadores del segundo período debe reconocerse primordialmente a Miranda y a Sharp. Una mención especial merece asimismo el recientemente desaparecido I. M. Johnston, a quien se debe una serie de contribuciones importantes que datan desde 1924.

\section{Agradecimientos}

La señora Ida K. Langman, así como los Dres. R. McVaugh, F. Miranda y A. J. Sharp tuvieron la amabilidad de leer el manuscrito y se agradecen sus opiniones críticas, correcciones y adiciones.

\section{ANALISIS FLORISTICOS QUE ABARCAN TODO EL PAIS}

Aunque Humboldt y Bonpland (1805) son probablemente los primeros en mencionar algunas afinidades florísticas de México, sus discusiones son aún tan poco precisas, que apenas es posible hacer referencia a ellas.

Fournier (1878a) estudia la distribución de los helechos en México y saca algunas conclusiones importantes. De acuerdo con este autor no hay diferencias significativas en cuanto a la composición de la flora pteridofítica entre las vertientes atlántica y pacífica del país. Existe una fuerte afinidad entre los helechos de México y los de las Antillas y de Sudamérica, especialmente en la región andina. La presencia de algunas especies comunes con las Islas Canarias, las Azores y la región mediterránea se interpreta como argumento en favor de la existencia de la desaparecida Atlántida.

En otro trabajo. Fournier (1884) se ocupa de la distribución geográfica de las gramíneas de México y en ese lugar confirma la conclusión acerca de la similitud de la flora de las vertientes atlántica y pacífica. Encuentra que de las 643 especies conocidas la mitad son endémicas del país y entre el resto existe un mayor número de taxa comunes con el Brasil y las Antillas. Expresa la opinión que la flora de México tiene afinidades concurrentes diversas.

Engler (1882: 187-230), al realizar un análisis de las floras del mundo, dis. cute la mexicana con bastante detalle en dos capítulos de su obra. Encuentra que la flora de la zona caliente de México, por debajo del cinturón de los encinos y los pinos, es de afinidades francamente meridionales y la incluye en la provincia subandina del distrito americano tropical, misma que abarca además casi toda Centroamérica, Colombia, Venezuela, Ecuador, Perú y Bolivia. Las porciones húmedas de esta provincia se caracterizan por una gran abundancia de Aráceas y Orquidáceas. 
La flora de las partes altas de México (incluyendo zonas adyacentes de los Es. tados Unidos y las montañas de Guatemala) se considera por separado. En ella se encuentra un gran número de elementos comunes con otras zonas de Norteamérica, situadas más a! norte. En las partes altas de las montañas se presentan géneros característicos de las regiones alpinas del globo. al lado de otros de distribución más local. Muchos de los géneros de la flora de México, de afinidad horeal, se encuentran también en los Andes sudamericanos, pero rara vez con las mismas especies. Igualmente el número de especies comunes con la flora de las Montañas Rocallosas es muy reducido.

Por otra parte, Engler llama la atención sobre la multitud de géneros comunes entre las regiones altas de México y las de los Andes, cuya gran parte se caract:riza por una distribución discontinua. El caso más notable representan las especies restringidas a las costas de California y de Chile.

En tercer lugar, se insiste en la riqueza de formas endémicas citando géneros restringidos a México, representativos de numerosas familias.

En conclusión. Engler deduce que las plantas habitantes de las partes altas de México no derivan de la flora de las zonas bajas de este país, sino se originaron a hase de inmigrantes procedentes de las latitudes altas de los hemisferios norte y sur, debido a que en esas últimas regiones ya existían con anterioridad formas características de clima templado. Tales formas estuvieron en ventaja con respecto a los elementos termófilos que habrían necesitado mucho tiempo para adaptarse a las temperaturas bajas y para colonizar los nuevos habitats creados por la elevación del terreno.

La discusión más completa de las relaciones geográficas y de los posibles orígenes de la flora de México es indudablemente la de Hemsley (op. cit., vol. 4: 138. 315). A este autor se debe la primera compilación crítica de los componentes conocidos de la flora mexicana, acompañada de un análisis fitogeográfico.

El trabajo de Hemsley, además de México, aharca toda Centroamérica, por to cual muchas de sus conclusiones se refieren a toda la zona en conjunto. No incluye en cambio la Península de la Baja California y prácticamente carece de datos referentes a la Península de Yucatán, cuya flora en aquella época apenas comenzaba a conocerse. Una buena parte del texto consiste de tablas sinópticas en las que se trata en forma estadística la distribución geográfica y las afinidades de las plantas. Las tablas son a su vez objeto de un análisis detallado. llegándose a las siguientes coilclusiones principales:

a) A pesar de la gran diversidad y riqueza de la flora de México, ésta no es tan altamente especializada como la australiana o la sudafricana, pues el número y la categoría de los endemismos son notablemente inferiores en la primera. Los géneros endémicos en México constituyen aproximadamente el $11 \%$ de su número total en la flora, siendo monotípicos más de la mitad de ellos.

h) La mitad meridional de México es florísticamente mucho más rica que la mitad 


\section{RZEDOWSKI, J., RELACIONES Y ORIGENES DE LA FLORA MEXICANA}

septentrional; además las dos presentan diferencias significativas para separailas en regiones fitogeográficas distintas.

c) Entre los géneros y las especies mexicanas cuya área de distribución se extiende más allá de los límites del país, hay un mayor número de taxa comunes con Sudamérica, quedando las Antillas, la América Noroccidental y la América Nororiental en el segundo, tercero y cuarto lugares respectivamente (no se hace $\mathrm{m}$ cómputo comparativo de afinidades entre México y Centroamérica).

d) Las relaciones de la flora del norte de México con la del oeste de los Estados Unidos son muy evidentes y partes de Arizona, de Nuevo México y de Texas pertenecen en realidad a la región fitogeográfica normexicana. La flora del este de los Estados Unidos, en cambio, tiene más en común con la del sur de México.

e) Las relaciones de la flora mexicana con la sudamericana son mucho más pronunciadas que con la antillana.

f) Aunque cuantitativamente poco apreciables, son significativas las relaciones de la flora mexicana con la del este de Asia, con Africa, con las Islas Galápagos, así como con las regiones antártico-andina y austral-asiática.

g) El norte de México debe considerarse como centro de origen de una flora xerófila peculiar, que más tarde se extendió hacia el sur y hacia el norte.

h) El sur de México se caracteriza principalmente por una mezcla de elementos boreales y meridionales que han evolucionado para originar un gran número de endemismos a nivel específico. Se citan a guisa de ejemplo los bosques de Quercus con un gran número de orquidáceas y bromeliáceas epifíticas, así como con otras plantas de afinidades sudamericanas. Entre estas últimas deben distingui:se las tropicales por un lado y las andinas por el otro. Lo mismo es aplicable a la flora de las altas montañas, en donde intervienen linajes andinos al lado de otros característicos de las cordilleras norteamericanas.

Gadow (1907-1909) intenta un análisis de la relativa importancia de los diferentes elementos de la flora del sur de México en función de la altitud. Distingue tres componentes principales: el boreal, el endémico y el meridional, e incluye un esquema en el cual representa las relaciones cuantitativas entre estos componentes a diferentes alturas sobre el nivel del mar. En números absolutos calcula que a unos 4000 a 5000 pies $(1200$ a $1500 \mathrm{~m}$.) de altitud se encuentra la mayor cantidad de (species, mientras que a unos 7000 pies $(2100 \mathrm{~m}$.) se registra el máximo de especies de afinidad boreal.

Cardot (1910: 79) analiza un grupo de 60 musgos hasta esa fecha conocidos de México y encuentra que 24 especies existen también en los Estados Unidos; 23 en América del Sur, especialmente en la región andina; 17 en Guatemala y en Costa Rica y 14 en las Antillas. El mismo autor considera que la mayor parte de los musgos boreales de la flora mexicana halla el límite meridional de su distribución en el Istmo de Tehuantepec. 
Harshberger (1911) en diferentes capítulos de su disertación sobre la fitogeo. grafía de Norteamérica dedica gran atención a México, aunque preferentemente a su vegetación. Las discusiones florísticas, muchas veces basadas en los análisis de Hemsley, incluyen algunos datos adicionales. El mencionado autor amplía la idea de que el norte de México ha sido en el Terciario el centro de evolución y dispersión de una flora xerófila. Siguiendo a Schumann (1899:21) considera a México como el territorio en que se originaron las Cactaceae; se adhiere a la idea de Trelease de que la Altiplanicie es la patria del género yusca. Cita también muchas otras plantas como originarias de este país. Por otra parte, sin embargo, Harshberger hace referencia a los trabajos de Bray $(1898,1900)$ señalando las significativas relaciones de algunos componentes de la flora xerófila de México y del suroeste de los Estados Unidos con la de las zonas áridas sudamericanas.

La flora de la parte tropical de México se considera derivada principalmente de la de Centroamérica, que a su vez está fuertemente ligada con la sudamericana. Harshberger divide la zona tropical de México en dos regiones: una correspondiente a la costa del Pacífico o Jalisciense, y otra correspondiente a la vertiente del Golfo.

Trelease (1924:23), en su revisión de las especies americanas del género Quercus, distingue en México las siguientes áreas de distribución de las 253 espe. cies del género:

1) Chihuahuense - incluyendo el norte del país

2) Californiana - extendiéndose a Baja California

3) La Sierra Madre Occidental

4.) La Sierra Madre Oriental

5) La Altiplanicie - incluyendo el Eje Volcánico Transversal, el Bajío y zonas adyacentes

6) La Cordillera - abarcando principalmente la Sierra Madre del Sur

7) Centroamericana - incluyendo las áreas al este del Istmo de Tehuantepec.

Standley (1936) discute las relaciones geográficas de la flora mexicana e insiste en su carácter altamente diversificado. Reconoce la existencia de varias regiones hotánicas bien delimitadas, de las cuales las más importantes son:

1) Los desiertos de Cactáceas, de Sonora, San Luis Potosí y Puebla.

2) La Península de Baja California, que posee una flora sui generis así como aiinidades con los desiertos costeños de Sudamérica,

3) La Sierra Madre (Occidental), cuya flora es distinta de la de las Montañas Ro. callosas, localizándose el límite entre amhas en el sur de los Estados de Arizon y Nuevo México. 
4) Los bosques de la tierra caliente, que se extienden hasta Sinaloa y los límites de Tamaulipas, alcanzando su mejor desarrollo en Veracruz, Oaxaca, Chiapas y Tabasco; son realmente una continuación de las selvas amazónicas, aunque poseen también especies endémicas,

5) La Península de Yucatán, región sobresaliente por sus afinidades antillanas y un considerable número de taxa de distribución local,

6) Las zonas alpinas, caracterizadas por sus especies endémicas, ligadas con la flora de las Montañas Rocallosas y de los Andes Sudamericanos.

Bravo (1937: 64-65), al discutir la distribución geográfica de las Cactáceas, reconoce en México cuatro principales zonas cactológicas:

1) La zona de las opuntias, que corresponde a la Altiplanicie

2) La zona de los grandes Cereus, situada en el sureste de Puebla y en regiones adyacentes de Oaxaca

3) La zona de las especies de tallos globosos, que se encuentra en el norte de los Estados de Chihuahua, Durango, Coahuila y Nuevo León.

4) La zona de las especies epifitas, localizada en los Estados de Veracruz, Tahasco y Chiapas

Williams (1951: 9-10), en su trabajo sobre las Orquidáceas de México, indica que el norte del país, la Altiplanicie y la Península de Yucatán tienen relativamente pocos representantes de esta familia. Las áreas de distribución de todos los géneros grandes tienen la forma de una Y encorvada, cuya base se encuentra en Chiapas, bifurcándose en Oaxaca, para seguir las ramas hasta San Luis Potosí y Jalisco a lo largo de las vertientes externas de las sierras. Otra zona subsidiaria de concentración de Orquidáceas se localiza en forma de una faja transversal situada en los de. clives meridionales del Eje Volcánico Transversal, entre Veracruz y Michoacán.

Aunque en 1926 sale a la luz el último fascículo de la monumental obra de Standley "Trees and shrubs of Mexico", no es sino hasta 1953(a) cuando Sharp publica el primer ensayo fitogeográfico basado en dicha monografía. Se trata de un estudio de las afinidades y de posibles orígenes de la flora de México, realizado a través de un análisis estadístico de la distribución geográfica mundial de las familias de dicotiledóneas leñosas existentes en el país.

Sharp encuentra que de las 143 familias representadas 54 son principalmente de distribución tropical y sólo 22 son características de regiones templadas. Hace referencia a la hipótesis de Schuchert de la elevación reciente de la Altiplanicie de México y de todos estos hechos concluye que la vegetación leñosa de México debe haber sido de tipo tropical desde sus principios y sólo hace relativamente poco tiempo (fines del Plioceno y Pleistoceno) tuvo lugar el desarrollo de la vegetación de tipo templado. 
Hernández X. (1959) analiza los tipos de distribución de las 1050 especies conocidas de Gramíneas de México y encuentra cuatro patrones fundamentales:

1) Regiones áridas y semiáridas del norte, centro y nor-oeste de México.

2) Regiones montañosas subhúmedas templadas.

3) Areas caracterizadas por condiciones edáficas especiales (principalmente salinas y yesosas).

4) Uhicuistas.

\section{ANALISIS FLORISTICOS REGIONALES}

\section{A) Baja California}

Antiguamente se creía que la flora de Baja California era semejante a la de la California Alta (Hemsley, op. cit., vol. 4:227), pero investigaciones ulteriores han revelado que esa aseveración sólo es verdadera en parte.

El estudio de las afinidades florísticas de esa zona se inicia con los trabajos de Brandegee (1889, 1892, 1893), quien encuentra que la Península puede dividirse en dos regiones bien diferenciadas, una boreal, cuya flora es semejante a la de la Alta California, y otra meridional, con flora muy ligada a la de Sonora. El límite entre ambas regiones lo sitúa el mencionado autor cerca de Calmallí, a la altura del paralelo $28^{\circ} \mathrm{N}$.

La parte meridional es objeto de un análisis más detallado (Brandegee, 1892), señalándose que el $10 \%$ de su flora la constituyen especies endémicas, el $25 \%$ existe también en la Alta California, pero las relaciones más estrechas son con las tierras situadas del otro lado del Mar de Cortés y existen algunas plantas ligadas con regiones situadas aún más al sur. En las zonas montañosas hay un mayor porcentaje de endemismos, pero se mantienen fuertes las afinidades con Sonora.

Nelson (1921: 103) encuentra que la flora de Baja California parece derivarse de tres fuentes principales: a) de la flora de las montañas y cerros del sur de California, que se extiende sobre las laderas de las Sierras de Juárez y de San Pednn Mártir cubriendo asimismo la mayor parte del área situada entre éstos y la costa del Pacífico; b) de la flora de los desiertos del noroeste de Sonora, sur de Arizona y sureste de California, que cubre alrededor de las dos terceras partes del territorio de la Península, a todo su largo y a veces a todo su ancho; c) de la flora de las partes áridas tropicales de la costa de México opuesta al extremo meridional de la Península; esta flora está limitada al tercio meridional de Baja California y es particularmente prominente en el distrito del Cabo.

Johnston (1921: 958-963), al discutir la fitogeografía y las relaciones geográ. ficas de la flora de Baja California, se adhiere a la idea de Brandegee acerca de la existencia de dos provincias florísticas, pero el límite entre ambas lo sitúa más al 
norte $\left(29^{\circ} 30^{\circ}-30^{\circ}\right.$ de latitud N). La provincia meridional la divide Johnston en dos distritos: el de las Sierras del Cabo y el de Comondú. El primero incluye las partes altas de la zona del Cabo y la Sierra Giganta, cuya flora presenta relaciones con California y con las zonas altas del Centro de México. El segundo, que incluye el resto del territorio, tiene flora con afinidades tropicales con un gran número de endemismos.

En otro capítulo de la misma obra (op. cit.: 966-973) se enfatiza la circunstancia que mientras la flora de Baja California es en su mayoría tropical y de afinidades mexicanas, la fauna de vertebrados está casi exclusivamente constituída por especies de origen norcaliforniano. Para explicar este fenómeno Johnston supone una conexión terciaria de la región del Cabo con la tierra firme de México y cree que después de la crisis pleistocénica se han extinguido casi todos los elementos tropicales existentes en la Península. Más recientemente los propágulos de las plantas procedentes del continente pudieron atravesar el Golfo y ocupar la porción sur de Baja California, no así los animales, dejando libre el terreno para su colonización por parte de los elementos inmigrantes del norte. En favor de esta hipótesis se pronuncia el hecho de que en las islas del Golfo de California que nunca tuvieron conexiones con la tierra firme existe una gran proporción de vertebrados de distribución restringida y casi ninguna especie endémica de plantas, lo que indicaría la mayor facilidad de transporte de diasporas de estas últimas.

Standley (1936:12) considera que la flora de Baja California posee tantas particularidades que no es fácil relacionarla con alguna otra del continente. Su mayor parte es endémica y entre sus elementos se hallan algunos comunes con Sudamérica.

Shreve (1937a), al estudiar la vegetación de la región del Cabo, confirma las observaciones de Brandegee, pero señala que muchas de las especies presentes en la costa de Sonora y Sinaloa no penetran a esta región de Baja California.

Epling y Harlan (1942) comparan las áreas de distribución de diversas especies características del chaparral y del matorral de Artemisia tridentata (sagebrush) de la costa de California y del norte de Baja California, y concluyen que estas plantas dehen haberse originado en la parte septentrional de México.

Carter (en prensa) se ocupa de las afinidades florísticas de la Sierra Giganta, situada en la parte sur de la Península y encuentra que estas se dirigen principalmente hacia la flora de la tierra firme de México. La autora considera que la flora de la Sierra Giganta y de la tierra baja contigua representa la expresión vivienie de la "Geoflora Madro-Terciaria" de Axelrod.

En un trabajo reciente Wiggins (1961) vuelve a analizar el problema de las relaciones geográficas y del origen de la flora de la Península, a la luz de invesígaciones modernas de su flora, de su vegetación y de su historia geológica. Este autor divide Baja California en 3 áreas fitogeográficas: la californiana. la capense y la del desierto central. La última ocupa la gran mayoría del territorio y es la que particularmente interesa a Wiggins, quien la subdivide a su vez en 5 subregiones. que coinciden esencialmente con las distinguidas por Shreve (1951). Para cada 
subregión se discuten someramente las afinidades florísticas. Un capítulo especial se dedica a la discusión de los posibles orígenes de la flora y se señalan 7 áreas de mayor significación cuyos elementos pudieron haber contribuído en el desenvolvi. miento de la flora regional: a) California, b) Gran Cuenca y Montañas Rocallosas, c) Desiertos Sonorense y Chihuahuense, d) Sierra Madre (compréndiéndose en ello las montañas del norte y centro de México), e) tierras bajas del sur de México, 1) zonas calientes del Centro y Sudamérica, g) litorales subtropicales. Se discuten asimismo las posibles rutas de migración.

Entre las plantas superiores se encuentran 13 géneros y muy numerosas especies endémicas, que en su mayoría están restringidas a la región capense o a la zona del desierto. Finalmente el autor señala la presencia en la flora bajacaliforniana de cerca de 40 familias representadas ahí por un sólo género o a menudo por una sola especie. Esta circunstancia se considera como un argumento en favor de la hipótesis de la juventud de la flora desértica de esta área.

Numerosas menciones acerca de las relaciones florísticas de las diferentes islas cercanas a las costas de Baja California se encuentran en trabajos diversos. Entre ellas merece atención especial la Isla Guadalupe (a $314 \mathrm{~km}$. de distancia de la Pe. nínsula), cuya flora parece tener muchas afinidades con la de la Alta California (Watson, 1876; Eastwood, 1929: 396). La última autora cree que estas relaciones sugieren la existencia de una antigua conexión con la tierra firme en forma de una península paralela a la de Baja California.

\section{B) Sonora}

De acuerdo con Johnston (1924: 958-959) la flora de la costa norte de Sonora. especialmente en la región cercana al río Colorado, es muy semejante a la del sur de California, con algunos elementos tropicales adicionales. El mismo autor cree que los elementos tropicales avanzan más hacia el norte en la zona interior de Sonora que en la costa. En la región de Guaymas (op. cit.: 963) la flora tiene muchos elementos comunes con la región del Cabo de Baja California.

Shreve (1936: 206-209) indica que existen pruebas fisiográficas de una fluc. tuación de la precipitación en el Desierto Sonorense en tiempos geológicos recientes y es posible que la temperatura también hava variado. Los períodos más húmedos y más calientes deben haber favorecido el desplazamiento al norte de los elementos del bosque espinoso situado inmediatamente hacia el sur. Debido a las condiciones fisiográficas las principales vías migratorias en Sonora y Baja California son en el sentido N-S o S-N. La distribución de las especies de los géneros Opuntia y Fero. cactus, cuyas áreas se sitúan en forma de una cadena alargada, suministran una prueba de estas migraciones acompañadas de actividades evolutivas.

White (1948: 254-266), en su estudio sobre la región del río Bavispe en al noreste de Sonora. dedica un extenso capítulo a las relaciones geográficas de su flora. White distingue los siguientes elementos: 


\section{RZEDOWSKI, J., RELACIONES Y ORIGENES DE LA FLORA MEXICANA}

1) Especies endémicas o restringidas a la región estudiada y zonas vecinas.

2) Especies del declive pacífico del norte de México, propias en su mayoría de clima caliente.

3) Especies de la Sierra Madre Occidental, algunas de las cuales también existen en la Sierra Madre Oriental y en el sur de México o están representadas ahí por formas vicariantes.

4) Especies de la Altiplanicie de México, cuyas áreas de distribución llegan generalmente hasta San Luis Potosí e Hidalgo, a veces hasta Puebla o Oaxaca.

5) Especies del occidente de los Estados Unidos, que se extienden desde el Valle del Misisipí hasta los estados de la vertiente pacífica y el norte de México.

6) Especies del oriente de los Estados Unidos, entre los cuales cita a Ostrya virginiana, planta que en opinión del autor debe haber llegado al noroeste de México en el Terciario, bien desde el noroeste o bien desde el este de los Estados Unidos.

7) Especies de amplia distribución en Norteamérica, divididas en dos grupos: uno de afinidades boreales y otro de relaciones tropicales.

8) Especies tropicales, entendiéndose como tales las que no existen más al norte de una línea entre Florida y California meridional.

9) Especies de distribución anómala, en donde se sitúa un grupo de distribución discontinua de elementos comunes con Sudamérica, y dos plantas comunes con Africa y norte de la India.

Para algunos datos relativos a la flora de Sonora véanse también las discusiones correspondientes a Baja California y al Altiplano Septentrional.

\section{C) Altiplanicie Septentrional}

Johnston (1943: 306-307), al iniciar una lista sistemática de plantas de Coahuila, este de Chihuahua y regiones vecinas de Zacatecas y Durango, indica que la flora característica de esa zona se extiende hacia el norte hasta el sur de Nuevo México y hacia el área de Trans-Pecos de Texas. Hacia el sur continúa hasta San Luis Potosí y muchas especies llegan a las partes áridas del centro de México. en Veracruz, Hidalgo y Puebla.

Rzedowski (1957: 58-59) en su estudio sobre la vegetación de las partes áridas de los Estados de San Luis Potosí y Zacatecas, cree que la región presenta elementos florísticos de procedencia muy diversa. Existen géneros comunes con las zonas áridas de Sudamérica y otros con los desiertos del Viejo Mundo. En terrenos montañosos prevalece el elemento más moderno que evolucionó en Norteamérica. Mu:chos géneros y familias, básicamente representadas en la flora de regiones húmedas han desarrollado especies adaptadas a condiciones de aridez. 
Al comparar la flora de los Desiertos Chihuahuense y Sonorense, Shreve (1942: 238) señala que de 12 plantas más características de cada zona sólo hay tres especies en común, lo que da una idea clara, aunque ligeramente exagerada de las diferencias florísticas entre ambas áreas. Diversos géneros están representados por especies vicariantes (op. cit.: 208-210).

Rzedowski (1961: 82-83) presenta una lista de especies de distribución relativamente limitada, comunes entre las partes áridas de San Luis Potosí y la zona sonorense. En otra lista da ejemplos de algunos géneros aparentemente evolucion dos en aquella última zona que no se han encontrado del lado oriental de la Sierra Madre Occidental.

\section{D) Tamaulipas}

Sharp et al. (1950) y Hernández X. et al. (1951) encuentran en la Sierra de Guatemala del suroeste de Tamaulipas la existencia de las comunidades vegetales semejantes a las que describen Miranda y Sharp (1950) de otras partes del este de México, en donde conviven elementos ampliamente distribuidos en el este de los Es. tados Unidos con otros de afinidad francamente tropical. Además de fanerógamas el análisis florístico incluye pteridofitas, briofitas y hongos superiores.

Turner (1959: 7), al definir las regiones florísticas del Estado de Texas, denomina tamaulipeca a una de las provincias distinguidas e indica que se trata eseilcialmente de una extensión boreal de la amplia región cubierta por arbustos mi. crófilos del noreste de México.

\section{E) Durango}

Maysilles (1959: 116-127) estudia la composición florística de los bosques de pino del occidente de Durango y hace notar que los componentes de las comunidades más mesófilas pertenecen principalmente a géneros de amplia distribución en las regiones de clima templado, en cambio las plantas propias de los bosques más abiertos y de los llanos son en su mayoría elementos de distribución restringida al Altiplano de México.

El autor llama la atención sobre el hecho de la existencia de un escaso pero significativo número de especies propias de las Montañas Rocallosas, casi ninguna de las cuales existe más al sur de Durango.

\section{F) San Luis Potosí}

La parte esencial de las discusiones florísticas incluidas en los trabajos sobre partes del Estado (J. Rzedowski, 1956: 210-211; G.C. de Rzedowski, 1960: 67-68; J. Rzedowski [en prensal) se encuentra también en el trabajo sobre la vegetación de toda la unidad administrativa (J. Rzedowski, 1961: 73-95), por lo cual se hará referencia únicamente a este último escrito. 


\section{Se divide San Luis Potosí en seis regiones florísticas:}

1) Región caliente y húmeda entre Aquismón y Tamazunchale; presenta relaciones florísticas meridionales prácticamente exclusivas, especialmente con la vertiente atlántica del sureste de México y con Centroamérica;

2) Región caliente y semihúmeda a algo seca de la Planicie Costera y de las primeras estribaciones de la Sierra Madre, en la zona de Ciudad Valles, también con afinidades meridionales, pero más bien con la vertiente pacífica de México y de Centroamérica; se caracteriza además por un gran número de especies endémicas, propias del noreste de México;

3) Región situada en las partes bajas y semiáridas del Altiplano, principalmente alrededor de la Llanura de Ríoverde; florísticamente similar a la anterior, pero con el elemento endémico aún más importante, a expensas de las afinidades con el sur de México;

4) Región húmeda y templada, ocupando una angosta franja situada en la Sierra Madre Oriental al oeste de la primera región, caracterizada por una mezcla de elementos de afinidad boreal (este de los Estados Unidos) y de otros de afinidad meridional, siendo fisonómicamente más importantes los primeros, pero más numerosos los segundos;

5) Región semihúmeda y templada de la Sierra Madre Oriental y de otras sierras del Estado, con flora característica de las altas montañas de México en general; dominan géneros con relaciones boreales (oeste de Norteamérica) y además hay numerosos elementos autóctonos y otros de afinidades meridionales, especialmente de tipo andino o de montaña en general;

6) Región de clima árido, cuya flora está ligada con la de las zonas áridas de México en general y con la del Desierto Chihuahuense en particular; predominan los géneros restringidos a México, además de otros de distribución neotropical.

De lo anterior puede deducirse que el clima caliente va correlacionado con la importancia del elemento meridional, el clima templado con el elemento boreal y al clima árido con el elemento autóctono; la aridez "favorece", además, el elemento meridional en perjuicio del boreal. Los últimos dos fenómenos parecen ser diametralmente opuestos al que denota la distribución de los mamíferos de la zona árida de San Luis Potosí, cuyas afinidades son holárticas.

La distribución discontinua de diversos taxa de San Luis Potosí no es fácil de explicar si no se piensa en cambios climáticos acentuados ocurridos en épocas pasadas. Probablemente los propios del Pleistoceno han sido los principales causantes de los fenómenos de disyunción. Existen pruebas, por otra parte, que los tres priıcipales constituyentes de la flora de México ya existían en su territorio desde el Terciario y deben haber experimentado ahí una intensa diversificación. 


\section{G) Islas Tres Marías}

De acuerdo con el análisis de Eastwood (op. cit.: 442) la mayor parte de las 324 especies conocidas de fanerógamas son de amplia distribución en los trópicos. Algunas son características de la tierra firme más cercana (más o menos $100 \mathrm{~km}$. de distancia) y 19 son endémicas.

\section{II) Islas Revillagigedo}

Johnston (1931), en su estudio sobre la flora de este archipiélago, distante cerca de $500 \mathrm{~km}$ de la costa sur de Baja California y casi $600 \mathrm{~km}$ del Cabo Co. rrientes de Jalisco, discute ampliamente las relaciones geográficas y los posibles origenes de la misma. De los 121 taxa conocidos 37 son endémicos. La mayor parte de las afinidades se dirige hacia la costa pacífica de México y hacia la Península de Baja California. Algunas especies, sin embargo, especialmente las endémicas, muestran ligas con el sur y con la vertiente atlántica de México, con El Caribe y con las Islas Galápagos.

Para explicar lo anterior Johnston cree que una parte de las plantas llegó in. dudablemente en tiempos más o menos recientes, transportadas probablemente por las corrientes marinas. En cuanto a las otras propone la hipótesis de que se trata de reliquias de tiempos pre-pliocénicos, en que una masa continental unía posiblemente el área de las islas con el resto de México.

Miranda (1960: 147) cree, en cambio, que no es necesario invocar la existencia de ese puente continental para explicar la presencia de algunos taxa isleños, que aunque hoy no existen en el oeste de México pueden haber vegetado ahí antes. Se observa además, que muchas de las especies arbóreas presentes son diseminadas por las aves y este puede haber sido el medio de que se valieron muchas plantas para colonizar las islas.

Cabe en este lugar mencionar la opinión de Hallier (1912: 9) quien, basándose en la composición florística de las Islas Sandwich y en algunas otras consideracio. nes, cree que las Islas Revillagigedo representan el resto de un antiguo puente continental transpacífico.

\section{I) Jalisco y Colima}

En su artículo sobre algunas Euphorbiaceae interesantes de Jalisco, Colima y zonas adyacentes McVaugh (1961: 146-147) incluye una breve discusión de las calracterísticas de la flora de la "Nueva Galicia". De acuerdo con este autor, la flora contiene un número considerable de elementos endémicos, independientemente de las especies restringidas al oeste de México, cuyo número llega quizá a constituir la mitad de todas las especies presentes en el área. El extremo nororiental de la zona se caracteriza por plantas peculiares de las praderas, mientras que la parie suroeste se asemeja florísticamente a las zonas vecinas de Michoacán y de la Sierra Madre del Sur. Aunque el área de distribución de muchas especies llega hasta Si- 
naloa y de algunas a la región capense de Baja California, casi no hay relaciones con la Planicie Costera del noroeste de México y son pocas las que le unen con la flora tropical de la costa atlántica del mismo país.

\section{I) Cuenca de México}

Herrera (1890) realiza un análisis de la flora del Valle de México y llega a la conclusión que ésta presenta más analogías con el norte que con el sur, especialmente con la Mesa Central de México.

Reiche (1914: 70-72) en su estudio acerca de la vegetación de los alrededores de la ciudad de México, que incluye también una lista completa de plantas conocidas, discute brevemente las afinidades de la flora. Encuentra que ésta está compuesta principalmente de "tipos templados", faltando la mayor parte de los grupos tropicales. Señala relaciones evidentes con la flora de los Estados Unidos y menos pronunciadas con la de la América caliente y con la región cordillerana de Sudamérica.

En otra contribución (Reiche, 1924) el mismo autor busca una caracterización florística de la mencionada área y basándose en la presencia, abundancia o ausencia de ciertos géneros y familias concluye que el Valle de México participa de los rasgos de la flora del Altiplano en general.

En términos más o menos similares resulta el análisis florístico del Pedregal de San Angel, pequeña área situada en el Valle de México, cuya vegetación fue estıdiada por J. Rzedowski (1954: 115).

\section{K) Zonas alpinas}

De acuerdo con el análisis de Hemsley (op. cit. vol. 4: 315) las plantas de la flora alpina de México pertenecen a géneros que pueden agruparse en varias categorías: a) de amplia distribución (grupo más numeroso), b) norteamericanos, c) sudamericano-mexicanos, d) sudamericano-norteamericanos, e) locales (muy po$\cos )$.

Según Heilprinn (1899: 243) la flora alpina de México posee muchos géneros en común con la de las regiones templadas de Norteamérica, pero las especies mexicanas son endémicas en su gran mayoría. Existe en cambio en México un grupo de especies comunes con la flora andina, cuya presencia es muy significativa.

Purpus (1908) considera que la flora de los pisos alpino y subalpino del Ixtarcíhuatl es esencialmente diferente de la correspondiente de las montañas del oeste de los Estados Unidos, pues faltan sus géneros más característicos como Astragalus, Oxytropis, Androsace, Saxifraga, Eriogonum, etc. Las afinidades andinas son notables a través de Pernettya ciliaris, Ranunculus sibbaldioides, Alchemilla spp., Halenia y otras. La flora subalpina del Popocatépetl es más pobre que la del Ixtaccíhuatl.

Gadow (1907-1909) distingue cuatro componentes de la flora alpina de México: a) boreal; b) endémico de México, derivado de la flora de la zona templada; c) 
meridional, derivado de la flora de los trópicos; d) andino. Su concepto de piso alpino difiere, sin embargo, del de otros autores, pues indica que al avanzar de la altitud de los 10,000 a los 13,000 pies $(3000-3900 \mathrm{~m})$ los géneros autóctonos van desapareciendo y los boreales quedan como dominantes.

\section{L) Cuenca del Balsas}

En su trabajo sobre la vegetación de la zona de Acatlán, Miranda (1943: 408) indica que la zona árida de la Cuenca del Balsas, aunque no participa de un modo completo de los caracteres florísticos de los desiertos del norte de México, presenti ciertos géneros en común con los mismos.

El mencionado autor (Miranda, 1947: 96), al discutir los rasgos de la vegeta. ción de la Cuenca del Balsas, señala que su flora posee un gran número de ende. mismos y es el área de mayor concentración actual de las especies del género Bursera. Al describir los diferentes tipos de vegetación existentes en la zona, indica sus relaciones geográficas, tanto las florísticas, como principalmente las ecológico-fitosociológicas.

Ramírez Cantú (1949: 208) en su estudio sobre la vegetación de la Sierra de Tepoztlán encuentra semejanza de la flora de esa zona con la de la región de Tan. cítaro en Michoacán y con la de Río Mayo en Sonora, conocidas gracias a los tra. bajos de Leavenworth (1946) y de Gentry (1942), así como con la flora del Pe. dregal de San Angel, contiguo a la Ciudad de México.

Espinosa (1961: 57-59) realiza un análisis de las afinidades de la flora de una corriente de lava en la Sierra de Chichinautzin y señala relaciones con las regiones holártica y neotropical. En general, esta flora está vinculada con la del sur de Mé. xico, habiendo especies de distribución limitada y otras cuya área se extiende a Centro y Sudamérica.

\section{M) Cuenca del Papaloapan}

La parte árida de la Cuenca alta del Papaloapan muestra, según Miranda (1948: 360-361) dos tipos evidentes de relaciones florísticas: a) con la flora de la Cuenca del Balsas, y b) con la flora de las barrancas áridas de las cuencas superiores de los afluentes del río Pánuco en la zona hidalguense-queretano-potosina.

\section{N) Chiapas}

En su monografía sobre la vegetación de Chiapas Miranda (1952, vol. 1: 21-4i) incluye un capítulo sobre las relaciones florísticas. Este autor encuentra que la flora del Estado, como la de todo México, pertenece en su mayoría a dos grandes regio. nes florísticas: la arctoterciaria y la neotropical. Los elementos de la primera se hallan principalmente en la zona de clima templado y frío, mientras que los de la segunda son característicos de clima caliente. aunque no hay una línea de demar. 
cación perfectamente definida y con frecuencia unos se mezclan con los otros. Además, existen algunos elementos andinos, de afinidad paleooceánica.

En - cuanto a las relaciones más inmediatas, la flora de la zona caliente de Chiapas es esencialmente surmexicana y fuertemente influenciada por elementos centroamericanos. Las plantas características del occidente de México se encuentran particularmente bien representadas en la depresión central de Chiapas, misma que también presenta algunas afinidades con la flora de la Península de Yucatán. La flora de las zonas chiapanecas calientes húmedas, en cambio, tanto en la vertiente atlántica como en la pacífica, presenta francas relaciones con el oriente de México. Estas dos zonas están separadas en la actualidad, pero su semejanza florística sugiere la existencia de una continuidad entre ellas en épocas pasadas.

La flora de las zonas templadas y frías de Chiapas concuerda en general asimismo con la del sur de México. Las relaciones con el occidente de México son más pronunciadas que con el oriente; entre los elementos comunes con la última región existen algunos que son plantas características del este de los Estados Unidos y presentan una distribución discontinua.

Miranda hace notar la escasez en Chiapas de los elementos característicos de las partes áridas del centro y norte de México, cuyas áreas de distribución terminan generalmente más allá del Istmo de Tehuantepec. Existen, sin embargo, algunas especies, que aunque ausentes en Chiapas, reaparecen en Guatemala, y diversos géneros reaparecen en Sudamérica, lo que sugiere una mayor continuidad de zonas de clima árido en épocas antiguas.

Se divide el territorio del Estado en ocho regiones florísticas, a mencionar:

1) Costa, con plantas que sólo viven en la cercanía del mar.

2) Llanuras y declives del norte del Macizo Central; zona de máxima afinidad con la región veracruzana.

3) Llanuras y declives del Soconusco; también relacionada con la región veracruzana, aunque en menor grado.

4) Declives del Golfo de la Sierra Madre; posee afinidades con los declives atlán. tico y pacífico de la Mesa Central de México.

5) Depresión central; relacionada con la región occidental de México.

6) Declive pacífico del noroeste de la Sierra Madre; que tiene muchas especies en común con la depresión central.

7) Macizo central.

8) Sierra Madre; posee muchas especies en común con la anterior.

Carlson (1954) analiza la composición florística del bosque de Pinus, Quercus y Liquidambar, situado en la región de Montebello en Chiapas. La autora encuentra 
que de las especies identificadas el $14.5 \%$ es común con el este norteamericano, en cambio el $67 \%$ tiene distribución restringida a México y Centroamérica. El 64\% de los géneros es de afinidad boreal y el $36 \%$ posee relaciones meridionales.

En un trabajo posterior Miranda (1957b) se refiere exclusivamente a la vertiente pacífica de Chiapas, distinguiendo tres regiones florísticas que coinciden esencialmente con la 3a., 6a. y 8a. de la división anterior. Se incluye una caracteriza. ción más amplia de cada una de ellas.

\section{O) Península de Yucatán}

En el capítulo introductorio a su flora de Yucatán Standley (1930: 164-165) discute algunos rasgos sobresalientes de las relaciones de la misma. Hace notar que a semejanza de las condiciones geológicas, fisiográficas y humanas, la Península se diferencia notablemente del resto del territorio de la República por su flora. Sus características principales consisten en un número relativamente grande de endemismos (3 géneros y $17 \%$ de las especies) así como en las afinidades con la flora antillana. Las últimas, que constituyen un hecho más bien excepcional entre las floras de México y de Centroamérica, resultan fácilmente explicables dada la cercanía de Cuba y de algunas otras islas del Caribe.

Swallen (1934: 325-326), Steere (1935: 396-397), L.B. Smith (1940: 106), Epling (1940a: 227), O'Neill (1940: 249-250) y Gleason (1940: 325-237), al revisar diferentes grupos de plantas de la Península de Yucatán, incluyen discusiones fitogeográficas, coincidiendo en sus conclusiones en términos generales, aunque la relativa importancia de los elementos antillano, mexicano, centroamericano, sudamericano y endémico varía de una familia a otra.

Woodson (1940: 61-76) intenta un análisis fitogeográfico basado en las Apocináceas de la Península y señala la existencia de especies endémicas pertenecientes a géneros francamente sudamericanos. No comparte la opinión de Grisebach que Yucatán debe incluirse en la provincia fitogeográfica antillana, pero confirma la idea de Schuchert de la existencia de conexiones continentales entre Centroamérica, las Antillas y Sudamérica en diferentes épocas y sitios.

Miranda (1957a: 76) indica que las relaciones de la flora de la Península de Yucatán son en primer lugar con la flora del resto del sureste de México, en segundo lugar con la de Centroamérica y en tercer lugar con la de las Antillas. Insiste asimismo en la alta proporción de especies endémicas.

Un año más tarde Miranda (1958: 217-221) amplía los conceptos anteriores y concluye que "buena parte de la flora de la Península de Yucatán parece haber derivado de la de regiones limítrofes continentales: sur de México y noroeste de Centroamérica. No obstante, dentro de la flora mexicana de tipo tropical (o de tierra caliente) la flora de la Península constituye una unidad bien definida". Este último hecho se fundamenta en la existencia de un número relativamente grande de especies endémicas y de otras comunes con El Caribe, pero ausentes de otras zon:s de México y Centroamérica. 
En lo relativo a las especies comunes con la flora antillana, es notable que la gran mayoría de ellas está limitada a la faịa costera del norte de la Península, lo que haría sospechar que se trata de una inmigración relativamente reciente a través de las corrientes marinas o del viento. Unas cuantas, sin embargo, se encuentran en el sur de la Península, y en este caso debe tratarse de una difusión más antigua. De todo lo anterior Miranda deduce que si bien la afinidad antillana de la flora yucateca es indudable, su magnitud no es tan grande como creían otros autores.

Tocante a la existencia de una porción elevada de formas endémicas, a pesar de la edad relativamente reciente de la Península (Mioceno a Pleistoceno), ésta puede explicarse en parte por las condiciones edáficas especiales y en parte por la invasión de formas antiguas procedentes de Belice.

De las islas cercanas a la Península de Yucatán solamente las correspondientes al Arrecife Alacranes (distante $111 \mathrm{~km}$ de la costa) parecen haber sido objeto de un estudio florístico detallado. De acuerdo con el reciente análisis de Bonet y Rzedowski (en prensa) su escasa flora (17 especies) está compuesta casi en su totalidad por plantas que existen también en la costa de Yucatán y cuyas afinidades son esencialmente antillanas.

\section{ANALISIS DE RELACIONES BOREALES}

Muchos autores, impresionados por los bosques de pino y encino que ocupan extensas zonas en las montañas de México, llamaron la atención sobre las analogías entre la flora de este país y la de las regiones templadas y frías de latitudes medias y altas del Hemisferio Boreal, especialmente en los Estados Unidos. Humboldt y Bompland (op. cit.: 16-17) son quizás los primeros en hablar de semejanzas florísticas entre los hosques de las partes altas de México con los de los Estados Únidos y Canadá. Engler (1882: 220) enumera diversos géneros comunes, pero es Hemsiey (op. cit.) quien discute el problema sobre bases firmes y lo define cuali y cuantitativamente (véase más arriba p. 127).

Hemsley (op. cit. vol. 4: 309), haciendo referencia a la aseveración de Gray (1878: 183) de que un grupo de gáneros característicos de los bosques de la vertiente atlántica de los Estados Unidos está ausente en los bosques de la región pacífica, hace la observación que todos estos géneros se encuentran representados en las montañas del sur de México, y algunos (Liquidambar, Ostrya, Carpinus) con especies idénticas, cuya área discontinua de distribución crea un problema fitogeográfico.

Watson (1890), Fernald (1931: 52.53) y McVaugh (1943: 140-144) hablan de relaciones entre la flora mexicana y la del este de los Estados Unidos, pero se refieren principalmente a elementos tropicales, australes o de origen mexicano, cuyos "vestigios" o "puestos avanzados" forman parte de la vegetación del sureste norteamericano.

Miranda y Sharp (op. cit.) estudian la vegetación y la composición florística de algunas regiones húmedas situadas en las montañas del este de México. Aunque 
la flora de estas regiones presenta afinidades diversas, los autores dedican particular atención a la discusión de las relaciones con el este de los Estados Unidos.

Miranda y Sharp encuentran que en ciertas localidades de la zona de transición de la "tierra caliente" y la "tierra templada" de las vertientes orientales y boreales muy húmedas de la Sierra Madre Oriental, del Macizo Central de Chiapas y de la Sierra Madre de Chiapas (fig. 1), así como en zonas análogas de Guatemala, existen comunidades vegetales en cuya composición florística entran muchos elementos de relaciones boreales. En todas ellas se encuentra presente Liquidambar styraciflua (fig. 2) al lado de otras especies típicas o relacionadas con las que tienen amplia distribución en el este de Norteamérica y pertenecen a grupos de deri. vación y evolución boreal. Otra categoría la constituyen los taxa de distribución geográfica francamente neotropical, hay algunos ligados con la flora del Caribe, otros endémicos de México y otros relacionados con el suroeste de los Estados Unidos. Aunque las especies de afinidades tropicales predominan numéricamente, las de tipo boreal constituyen casi siempre las dominantes de la comunidad.

Ninguna otra zona de México parece estar tan relacionada por su flora con el este norteamericano, y la máxima concentración de la afinidad se encuentra entre Zacualtipán, Hgo. y Jalapa, Ver. y en la Mesa de San Cristóbal, en Chiapas.

Los autores señalan el caráeter discontinuo de la distribución geográfica de muchos de los taxa discutidos, pues existe un aparente hiatus de 800 a $1000 \mathrm{~km}$ entre el este de Texas y el sur de San Luis Potosí, correspondiendo con regiones en que la humedad no es suficiente para la existencia de estas plantas.

Se llama asimismo la atención sobre la significativa semejanza de la flora de la zona estudiada con la flora fósil de la formación Wilcox del Eoceno de los Es. tados Unidos, tema desarrollado por Sharp en otro artículo (1951).

Directamente ligados con el problema discutido en el trabajo de Miranda y Sharp pueden considerarse las siguientes contribuciones:

a) Las de Sharp $(1945,1946 a, 1946 b)$, en donde se exponen resultados preliminares de los mencionados estudios florísticos,

b) La de Sharp (1948), señalando la existencia de diversos hongos superiores, cuyas áreas de distribución se asemejan a las de las plantas de otros grupos;

c) Las de Sharp et al. (1950) y de Hernández X, et al. (1951), quienes describen otra área de características similares en el suroeste de Tamaulipas;

d) La de Crum (1951), donde se agregan más pruebas derivadas de un análisis minucioso de la distribución geográfica de 259 especies de musgos comunes a México y los Estados Unidos,

e) La de Leopold (1950: 514), quien cita otras localidades, entre ellas una en la Sierra Madre del Sur en el Estado de Guerrero, 


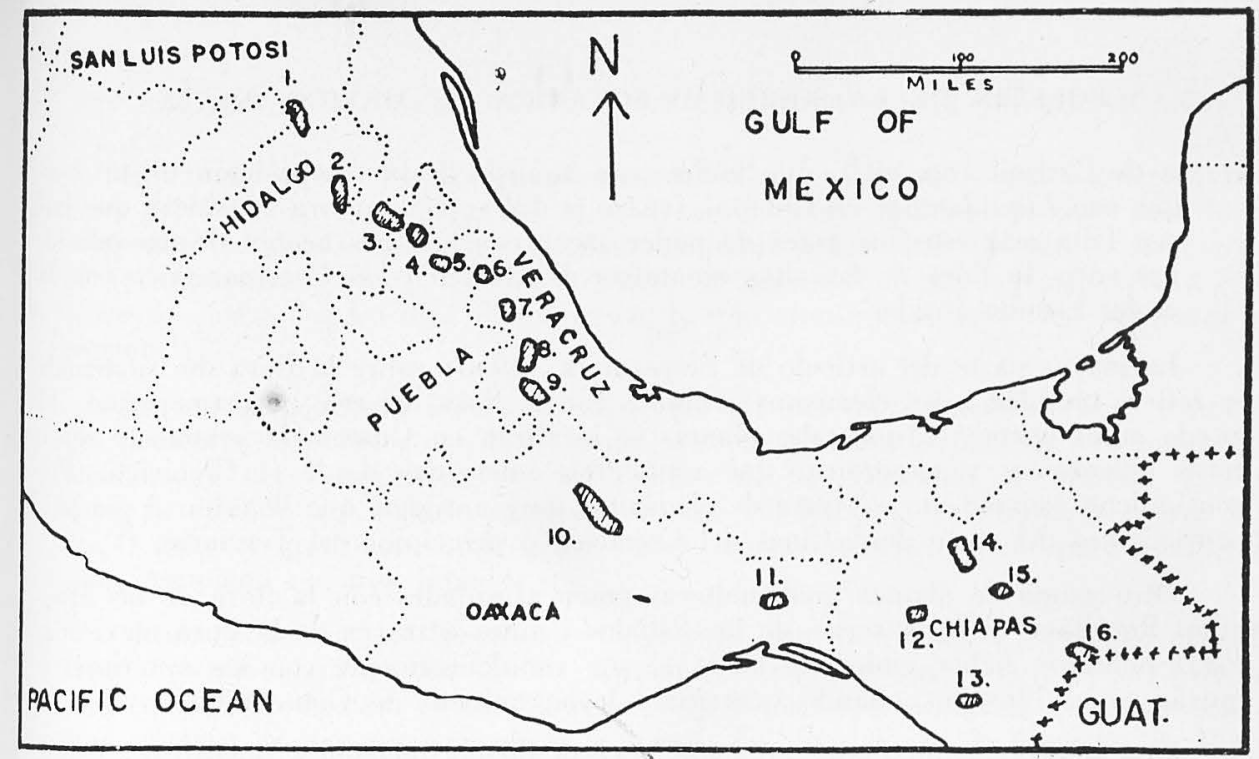

Fig. 1 Localidades estudiadas por Miranda y Sharp, en cuya composición florística intervienen numerosos elementos de afinidades boreales (según Miranda y Sharp, 1960).

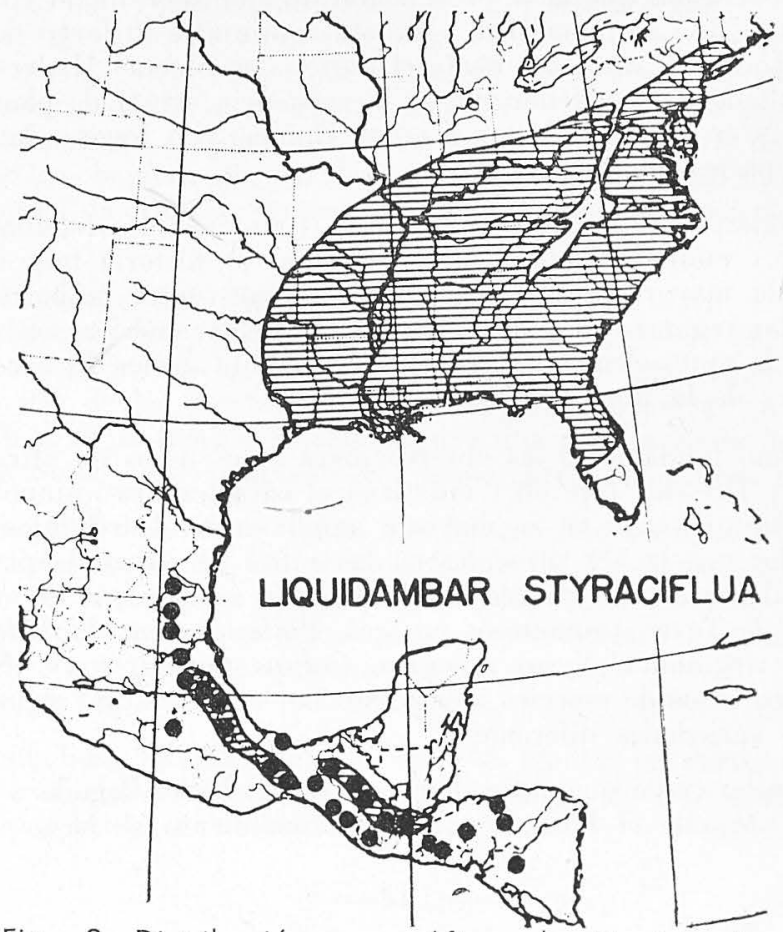

Fig. 2 Distribución geográfica de Liquidamba: styraciflua, según Marìin y Harrell, 1957. 
1) la de Carlson (op. cit.), que incluye un análisis de la composición de un bos. que con Liquidambar en Chiapas (véase p. 139) ; esta autora considera que hacen falta más estudios antes de poder sacar conclusiones acerca de las relacio. nes entre la flora de las altas montañas de México y de Centroamérica con la de los Estados Unidos.

La mayor parte del artículo de Steyermark (1950) sobre la flora de Guatemala se refiere también a los elementos comunes con la flora del este norteamericano. El citado autor encuentra que tales plantas se localizan en Guatemala solamente sobre rocas paleozoicas y mesozoicas que estuvieron emergidas desde el Cretácico. Por consiguiente supone que se trata de elementos muy antiguos que llegaron a ese país provenientes del norte desde fines del Cretácico o principios del Terciario.

Otro grupo de plantas guatemaltecas posee afinidades con la flora de las Montañas Rocallosas y del suroeste de los Estados Unidos a través de la flora mexicana. Estas pudieron haber emigrado hacia el sur simultáneamente con las anteriores 0 quizás en el Plioceno, cuando ocurrió el levantamiento de Guatemala.

Una interpretación diametralmente opuesta de las relaciones florísticas "borea. les" de la flora mexicana se debe a McVaugh (1952), quien ha estudiado con de. talle la taxonomía, la distribución geográfica y las relaciones filogenéticas de los taxa incluidos en los grupos Prunus serotina y Lobelia cardinalis. El mencionado autor llega a la conclusión que la diferenciación de ambos se inició en las montañas del sur de México y de Centroamérica, y de ahí continuó a lo largo de dos vías mí. gratorias bien definidas y dirigidas hacia el norte: las Sierras Madres Occidental y Oriental. El resultado de este fenómeno es la existencia actual de plantas bien diferentes en el este y en el oeste de los Estados Unidos, con formas intermedias presentes en varias partes de México.

McVaugh sugiere que muchos otros grupos (por ejemplo Arbutus, Cercis, Carpinus, Ulmus, etc.) pudieron haber tenido este tipo de historia migratoria y evolltiva y cree que la mayoría de los elementos comunes entre la parte templada de Norteamérica y las regiones altas de México y de Centroamérica son de origen tro. pical, siendo por lo tanto elementos australes de la flora de los Estados Unidos y no elementos boreales de la flora mexicana.

Tomando como fundamento las observaciones y los datos de Miranda y Sharp. Crum (op. cit.) y Dressler (op. cit.) enfatizan el carácter discontinuo del área geo. gráfica de un grupo de taxa en su mayoría ampliamente distribuidos en el este de los Estados Unidos y a la vez presentes en las zonas de clima templado y húmedo de las montañas del este y del sur de México, siendo ausentes en el norte del último país y en el sur de Texas (numerosos musgos, Pinus strobus, Liquidambar styraci. flua, Hamamelis virginiana, Nyssa sylvatica, Cornus florida, etc.). Se trata en la mayor parte de los casos de especies idénticas o tan cercanas que algunos autores las consideran como variedades diferentes.

Crum y Dressler creen que estos elementos deben haber llegado a México procedentes del norte durante el Pleistoceno. Su razonamiento se hasa principalmente: 
10. en la suposición basada en algunos trabajos geológicos y paleontológicos que antes del Plioceno no existían en México condiciones climáticas propias para la inmigración de plantas mesófilas de clima templado procedentes del este norteamericano (véase también Sharp, 1953a: 377-378) y 2o. en el hecho de la identidad específica de casi todos los taxa discontinuos, lo que atestiguaría su arribo relativamente reciente.

En contraste, como señala Dressler, las plantas mexicanas de clima templado que presentan afinidades con la flora del oeste de los Estados Unidos casi nunca son idénticas al nivel específico con las plantas de las Montañas Rocallosas. Ello se debe, en opinión del mismo autor, a que desde el Mioceno existió ya la Sierra Madre Occidental que pudo servir como vía de dispersión hacia el sur para plantas de clima templado no muy húmedo.

Crum encuentra que los musgos mexicanos presentan a nivel específico una afinidad dos veces mayor con el este norteamericano que con el oeste y la distribución en el segundo caso es casi siempre más o menos continua en contraste con el gran número de disyunciones en el primero. En oposición a la hipótesis de White (véase p. 133) este investigador cree que algunas plantas de afinidad oriental que existen en Sonora y Arizona pueden haber llegado ahí desde el centro de México a través de la Sierra Madre Occidental.

Braun (1955) y particularmente Martin y Harrel (op. cit.) también se ocilpan de la significación de esias reliquias arctoterciarias presentes sobre todo en el este y en el sur de México, pero se adhieren a la creencia de que su difusión data desde el Terciario Medio o de épocas anteriores. En el Plioceno debe haberse producido el aislamiento a causa del desarrollo de una barrera de clima árido en el norte de México, barrera que no dejó de funcionar como tal ni siquiera durante el Pleistoceno, impidiendo un contacto efectivo y manteniendo la separación de las áreas.

Para reforzar esta hipótesis Martin y Harrell recurren a pruebas zoogeográficas y señalan que son muy pocos los vertebrados del este de los Estados Unidos que se hallan actualmente en México y menos aún los que tienen áreas discontinuas semejantes a las de las plantas. En cambio, creen encontrar en la distribución de las salamandras de la familia Plethodontidae una prueba de la llegada a México de elementos de clima cálido-templado en tiempos prepleistocénicos (Cenozoico medio).

Axelrod (1960: 268-269) opina que la conexión entre las áreas hoy disyuntas puede datar del Eoceno, del Paleoceno o quizás de! Cretácico mismo. Como pruebas en favor de tal idea aduce la presencia de elementos arcto-terciarios (algunos de ellos muy próximos a los que actualmente se caracterizan por un área discontinua) en la flora de los cerros que rodeaban la Cuenca del Green River en las Montañas Rocallosas en el Cretácico y en el Paleoceno.

Sobre esta base Axelrod concluye que las plantas en cuestión poseían una dis tribución que se extendía hasta México a lo largo de las montañas bajas que se encontraban esparcidas en la región. A su juicio no se requeria para ello la pre- 
sencia de altas serranías, puesto que en esa época la zonación climática del mundo era mucho menos pronunciada que ahora, y en consecuencia las zonas tropicales eran menos calientes, mientras que las de latitudes altas eran menos frías.

Es pertinente mencionar también en este sitio la opinión de Reinig (1937), quien considera que el norte de México ha funcionado como refugio de especies holárticas durante el Pleistoceno. Este autor deduce la existencia de un clima húmedo en esa época, hasándose en la ausencia de depósitos de loess en la mencionara región.

Bader (1960), sin entrar en problemas de interpretación, revisa una extensa bibliografía con el fin de resumir los datos relativos a la distribución geográfica de plantas leñesas boreales y subantárticas en las montañas intertropicales. La información referente a México ocupa mucho espacio en esta voluminosa obra, aunque el enfoque se concentra fundamentalmente alrededor de los límites altitudinales y latitudinales de las áreas de los géneros y de las especies.

\section{ANALISIS DE RELACIONES MERIDIONALES}

El elemento meridional es sin duda el componente cuantitativamente más importante de la flora de México. Ello se deduce de los cálculos de Hemsley (op. cit.), de Sharp (1953a) y de muchos otros datos de la literatura.

El último autor (op. cit.: 378) supone que la riqueza de la flora tropical de México se debe a la relativa complejidad de su origen, pues está compuesta de a) elementos desarrollados in situ, b) elementos que llegaron del sur, y c) elementos que llegaron del norte.

Es obvio, que, a semejanza del elemento boreal, también el meridional incluye en realidad varios tipos de relaciones geográficas. Hemsley (op. cit. vol. IV: 228) distingue entre las afinidades con el oeste de Sudamérica y el este de Sudamérica para diferenciar a grandes rasgos la zona andina de la zona amazónica. Además se ha insistido modernamente en las significativas relaciones florísticas entre las zonas áridas de Norte y Sudamérica.

En general, los autores coinciden en la gran analogía entre la flora del sur de México y la de Centroamérica, especialmente de la mitad septentrional de la última (Hemsley, op. cit.; Standley, 1928: 31, 1937: 43-45; Bartram, 1929: 349; 1932: 177; Standley y Record, 1936: 52-55; Lundeil, 1937: 204-205; y otros), de manera que comúnmente se les considera formando una sola provincia fitogeográfica.

Steyermark (op. cit.: 370 ) afirma que la flora de Guatemala es esencialmente de tipo mexicano y en particular surmexicano, o sea que la mayor parte de los géneros ahí encontrados existen también en México. Esta afinidad se manifiesta tanto en las plantas de clima templado, como en los elementos propios de clima caliente. muchos de los cuales tienen un área de distribución ininterrumpida desde Sinaloa o Veracruz hasta el norte de Sudamérica. 
Miranda (1960b) realiza un análisis comparativo de las afinidades de la flora arbórea del sureste de México con las de diferentes regiones boscosas americanas, y encuentra que el número de géneros comunes disminuye al avanzar hacia el ecuador para-aumentar en Brasil, del otro lado del mismo, y finalmente para volver a disminuir en la región templada de Chile. La máxima afinidad se localiza en Belice; la de Costa Rica es más o menos equivalente a la de Cuba, pero ambas resultan superadas por la de la flora fósil del Eoceno de la formación Wilcox del este de los Estados Unidos.

Rzedowski (1961: 73-78), en su trabajo sobre la vegetación del Estado de San Luis Potosí, encuentra una afinidad florística meridional prácticamente exclusiva en las porciones bajas, calientes del Estado.

La presencia de elementos florísticos comunes entre regiones extratropicales de Norte y Sudamérica llamó la atención de los botánicos desde hace mucho tiempo. Bentham (1873: 527-528), al estudiar la distribución geográfica de los miembros de la familia Compositae, presenta una lista de géneros comunes entre ambas áreas y ausentes del cinturón tropical intermedio. El mencionado autor concluye que este hecho sólo puede explicarse suponiendo la existencia en otras épocas de condiciones ambientales diferentes que permitieron una migración gradual, o bien la colonización a través de vías que aparentemente hoy no existen.

Engler (1882: 224-227) y Hemsley (op. cit. vol. IV: 299, 314) insisten en la gran importancia de los géneros de afinidad andina en la flora de las montañas de México y creen que en algunas épocas anteriores hubo posibilidades de migración e intercambio de elementos de clima templado hacia el norte y hacia el sur, a lo largo del continente americano.

Bray (1900: 713) llama la atención sobre el hecho de que las altas montañas de México y de los Andes poseen muchos géneros comunes con la flora de las zonas frías de Europa, Asia y Norteamérica. Existe también un número de especies comunes entre las Montañas Rocallosas y el extremo sur de Sudamérica, que faltan en México y en los Andes. Estos tipos de distribución transtropical han sido objeto de amplia discusión en el trabajo de DuRiéz (1940), quien postula la existencia de puentes montañosos en el Cretácico, a través de los cuales las poblaciones primitivas continuas han desarrollado formas similares en el norte y en el sur.

Epling (1939), al estudiar los tipos de distribución geográfica de los miembros de los diferentes grupos de Salvia, subgénero Calosphace, determina tres patrones característicos de áreas, de los cuales uno incluye las partes altas de México y los An: des, y otro las partes altas de México y del Brasil. Un año más tarde (Epling, 1940b: 574-575) el mismo autor estudia la distribución geográfica de toda la familia Labiatae y puntualiza que el área de concentración situada en el norte de México muestra relaciones estrechas con los centros cordobense (Argentina), chileno y brasileño. El área del centro de México, en cambio, está estrechamente ligada con la zona de los Andes Centrales y con la brasileña.

Una atención especial ha recibido en la literatura el problema de los taxa co- 
munes entre las zonas áridas de Norte y Sudamérica, separadas actualmente por un amplio cinturón de clima y vegetación tropical húmeda.

Gray y Hooker (1880: 57-60) presentan una lista de 90 especies o géneros comunes entre el suroeste de Norteamérica y ciertas zonas de Sudamérica, especial. mente Chile, y suponen que su migración se efectuó en épocas en que è clima era más fresco que el actual.

Bray (1898, 1900), haciendo referencia al trabajo anterior y al de Engler (1882), señala específicamente las relaciones entre las floras xerófilas de México y del suroeste norteamericano y las correspondientes de Chile y Argentina, llamando la atención sobre la actual distribución discontinua de diversos grupos. El mencio. nado autor supone la existencia en alguna época pasada de una zona montañosa más continua a través del trópico, con la presencia consiguiente de fajas áridas que establecerían una comunicación más efectiva entre las partes secas de Norte y Sudamérica. En esta forma pudo haberse realizado un intercambio de floras: los elementos australes llegaron al norte y los elementos boreales migraron hacia el sur.

Engler (1914: 619), al referirse a las relaciones entre las floras xerófilas norte y sudamericanas, piensa que la distancia entre estas dos zonas áridas no es superior a la que separa las regiones desértica asiática y australiana y cree que los propios medios de diseminación de las plantas en cuestión deben ser los responsables de la distribución actual. Por otra parte señala la posibilidad que las regiones semiáridas antillanas pudieron haber servido de camino para la dispersión de xerófitas.

Standley (1916) hace una comparación de la flora del Valle de la Mesilla en Nuevo México, con una colección de unos 300 ejemplares recogidos en Río Negro, en el sur de Argentina, encontrando 20 especies comunes y 45 especies estrechamente emparentadas en ambas áras.

Arldt (1919) vuelve a insisiir sobre la posible importancia del arco antillano como ruta de migración, y además discute las probabilidades de la existencia de un puente continental situado al poniente de Centroamérica, cuyos restos estarían representados por las islas Revillagigedo, Galápagos, Cocos, Malpelo, y tal vez Juan Fernández.

Krüger (1934) realiza un análisis detallado de los miembros de la familia Gramineae que presentan una distribución restringida a la zona árida del Altiplano de México y la argentino-boliviana. Encuentra 16 especies con este tipo de disyunción, además de 6 pares de especies vicariantes. Al discutir las supuestas causas de tal distribución geográfica, Krüger rechaza la posibilidad del desarrollo evolutivo convergente y del origen a partir de un antecesor común de afinidad mesófila. Se inclina hacia la hipótesis de una mayor continuidad de zonas áridas en épocas pasadas.

Johnston (1940) lleva adelante la idea de la importancia de los linajes florís. ticos comunes entre las regiones áridas de Norte y Sudamérica. Señala una dife. rencia básica entre las plantas herbáceas que parecen haber tenido un origen relativamente moderno en Nortemérica, y las leñosas que en su opinión han evolucio- 
nado en el Hemisferio Sur y son antiguos elementos desérticos. El artículo se ocupa específicamente de la significación fitogeográfica de estos últimos.

Johnston inicia la discusión indicando la presencia de tres especies arbustivas (Larrea divaricata (fig. 3), Atamisquea emarginata, Koeberlinia spinosa) en las zonas desérticas de México y Estados Unidos por una parte y de Argentina y Bolivia, por la otra. Encuentra asimismo que numerosas especies xerófilas sudamericanas presentan taxa vicariantes en la zona árida norteamericana. Hace hincapié en la abundancia de formas áfilas y de formas provistas de secreciones resinosas entre los arbustos desérticos sudamericanos, y cree altamente significativa la presencia de estas características en las especies existentes en las partes áridas de Norteamérica, cuyas afinidades las ligan con plantas del sur.

El mencionado autor cree que se trata de elementos de una flora desértica muy vieja (de principios del Terciario), compartida por ambos hemisferios. En América del Sur esta flora sigue estando bien conservada, mientras que en Norteamérica sólo sobreviven sus vestigios, que no han desaparecido ante la competencia de xerófitas más modernas. Johnston supone la existencia en alguna época de un contacto efectivo entre ambas zonas áridas, a través de lo que es hoy la zona ecuatorial húmeda.

Axelrod (1948: 140-142) ofrece una explicación muy diferente de las semejanzas florísticas entre las dos áreas mencionadas. En su concepto las zonas áridas en América nunca eran tan extensas como lo son ahora y por lo tanto es imposible pensar en un contacto transecuatorial. Tomando como base la idea de DuRietz (op. cit.) este autor sugiere que las formas xerófilas vicariantes pudieron haber evolucionado paralelamente a partir de un antecesor común propio de climas húmedos que habitaba la región tropical que en otra época era mucho más amplia que actualmente. Para explicar las áreas discontinuas de Larrea, Atamisquea y Koeberlinia Axelrod propone en una publicación posterior (1950: 285) el transporte de propágulos a larga distancia desde Sudamérica hasta Norteamérica.

García, Soto y Miranda (1960) consideran que la hipótesis de Axelrod de emigración a larga distancia no parece aceptable. Son partidarios de la idea de una mayor continuidad entre las zonas secas americanas en el pasado. La distribucióa actual de los géneros Cercidium (fig. 4) y Castela (fig. 5) señala que esta conexión pudo haber existido a lo largo del arco antillano y de la costa occidental de Sudamérica. Puesto que Larrea requiere, además, de un clima no excesivamente caliente, los autores suponen que las temperaturas en la zona tropical americana fueron más bajas en épocas pasadas de lo que son en el presente.

\section{ANALISIS DE RELACIONES CON OTRAS REGIONES}

Es lógico pensar que por su situación geográfica las afinidades de la flora de México se concentran sobre todo en las direcciones norte y sur. 


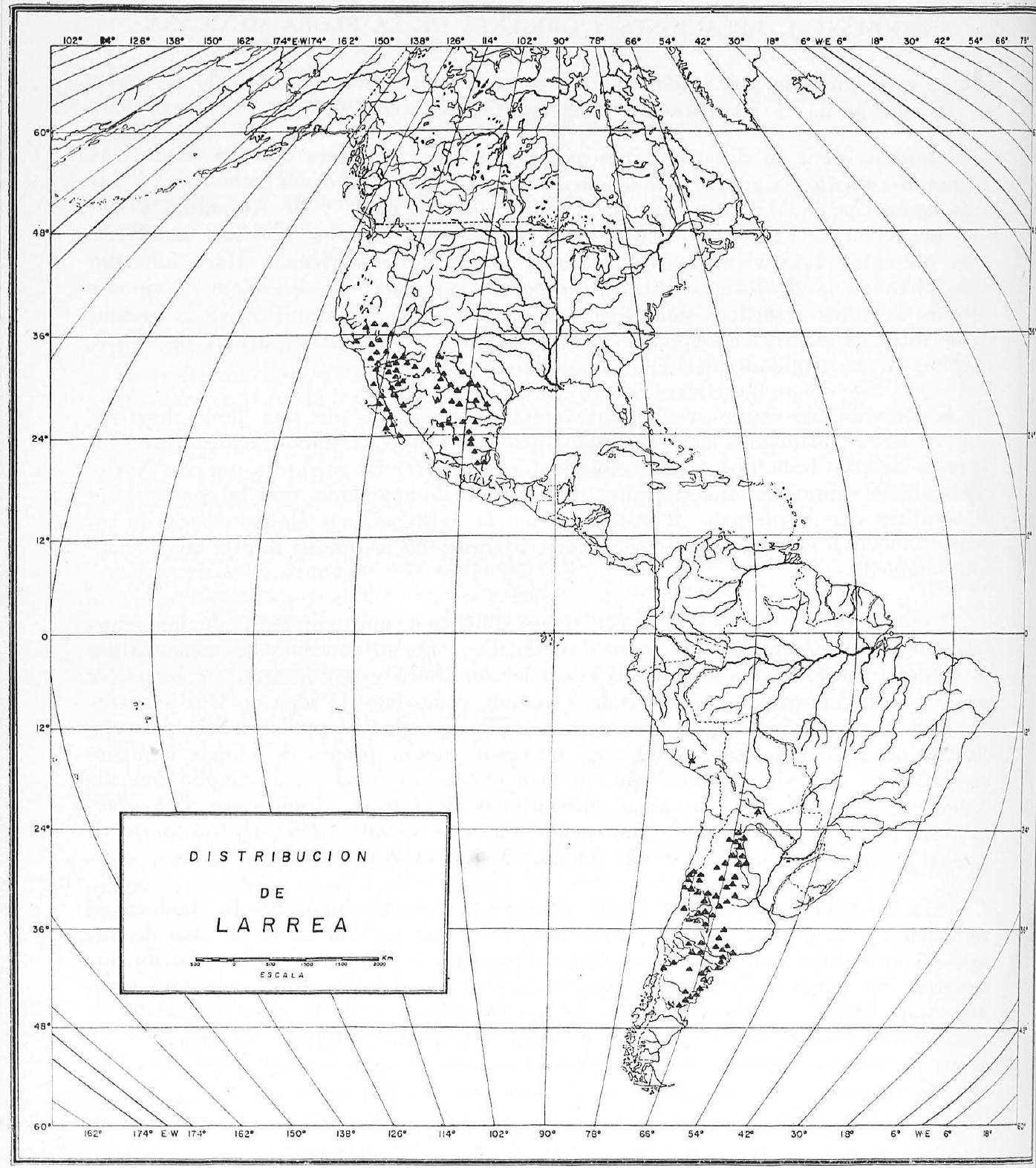

INSTITUTO DE GEOGRAFIA

UNIVERSIDAD NACIONAL AUTONOMA OE MEXICO $\triangle$ Locolidad con Larraa

Fig. 3 Distribución geográfica de Larrea, según García, Soto y Miranda, 1961. 


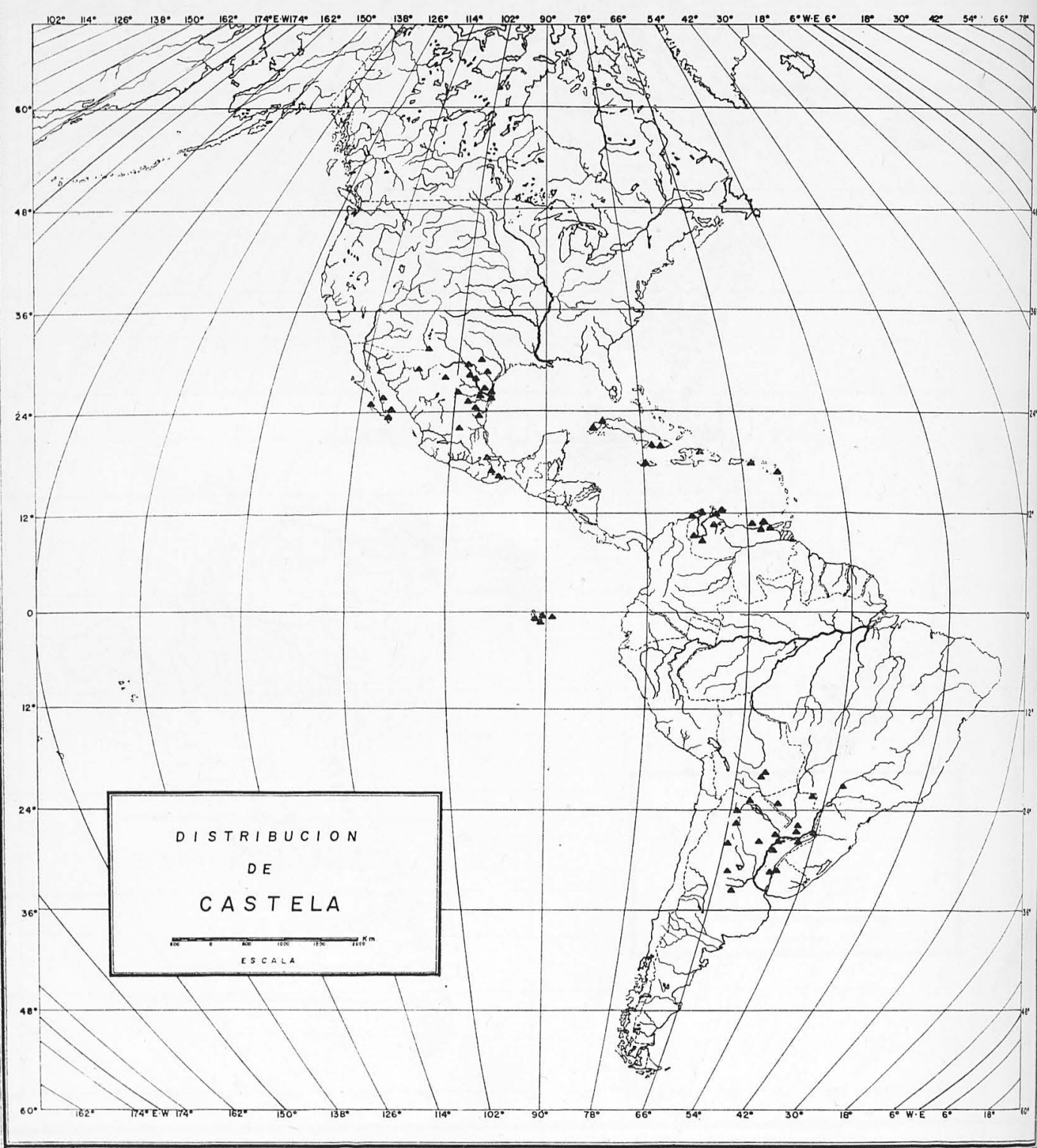

INSTITUTO DE GEOGRAFIA

UNIVERSIDAD NACIONAL AUTONOMA DE MEXICO - Localidad con Castela

Fig. 5 Distribución geográfica de Castela, según García, Soto y Miranda, 1961. 
Aunque cuantitativamente mucho menos importantes, resultan evidentes también las afinidades con algunas otras regiones, como lo han observado diferentes aultores, especialmente Hemsley (op. cit. vol. IV.: 227-235).

\section{A. Relaciones con las Antillas}

El carácter insular de las Antillas y su complicada historia geológica son las probables causas de las relativas diferencias entre su flora y la de México.

Grisebach (1878, vol. 2: 515) es quizás el primero en referirse a esta circunstancia, al observar que la mayoría de las especies comunes entre ambas áreas son plantas de distribución mucho más vasta.

Hemsley (op. cit. vol. 4: 227-228), en una tabulación estadística de afinidades florísticas encuentra un gran número de taxa comunes entre México y Sudamérica, pero ausentes en las Antillas; en cambio la mayoría de las especies presentes en México y en El Caribe se hallan también al sur del Istmo de Panamá.

Harshberger (op. cit.: 305-311) cree que El Caribe tuvo largos períodos de evolución florística independiente, especialmente las Antillas Mayores, que han desarrollado una flora característica con numerosos endemismos.

Un trabajo pertinente al problema es el de Trelease (1918), quien discute la existencia de posibles conexiones entre Cuba y el continente a base de la distribución actual de los géneros. Agave, Yucca, Phoradendron y Quercus.

Schuchert (1935: 79-113), quien se ocupa en detalle de las conexiones continentales presentes en épocas pasadas en la región antillana, revisa las pruebas biogeográficas aplicables a su hipótesis.

Johnston (1931: 30-34) observa en las Islas Revillagigedo la presencia de algunos taxa relacionados con la flora del Caribe.

Standley (1936: 16) plantea el problema de la mayor cantidad de elementos de la flora antillana en la costa pacífica de México en comparación con la costa del Golfo, exceptuando la Península de Yucatán.

Alain (1958: 54-56) insiste en una gran semejanza entre la flora centroamericana (incluyendo México) y la de las Antillas Mayores y cree que la mayor parte de los elementos de esta última proviene de Sudamérica, a través de un puente continental entre Honduras y Cuba.

Acerca de las afinidades florísticas entre la Península de Yucatán y las Antillas véase la discusión en el capítulo III, inciso $O$ de este trabajo.

B. Relaciones con Asia

Hemsley (op. cit. vol. IV: 228-229), al señalar la presencia de elementos comunes entre la flora mexicana y la asiática, indica que muchos de los géneros exis- 
tentes en México y en el este de Asia se encuentran también en el este de Norteamérica.

Hallier (op. cit.) enumera una serie de géneros comunes entre América y Australasia y sobre esta base postula la existencia en épocas antiguas de un amplio puente continental transpacífico, cuyo extremo boreal debía haber estado situado a lo largo de una línea que corre del sur del Japón a través de las Islas Sandwich y Revillagigedo hacia Baja California.

Sharp (1951), a través de su estudio de las afinidades de la flora fósil del Eoce. no del sureste norteamericano, deja establecidas indirectamente las relaciones entre las floras actuales de México y del Lejano Oriente. Este autor, en un artículo pos. terior (Sharp, 1953b), realiza un análisis de los géneros comunes entre México y Asia oriental y encuentra que algunos de ellos están ampliamente distribuidos en Norteamérica, otros sólo en su porción oriental y otros están restringidos a Méxien y Centroamérica.

Matuda (1953) enumera una serie de plantas de la flora mexicana pertenecientes a grupos cuya principal zona de distribución actual se encuentra en Asia.

Miranda (1960b), en su estudio sobre los géneros bicontinentales en la flora tropical americana, habla de un grupo "anfipacífico" o de elementos asiático-americanos, que caracterizan las regiones montañosas, sobre todo hacia el límite de la zona tropical. Se sugiere (op. cit.: 13) que en el pasado las floras arbóreas de diferentes zonas tropicales pudieron haber intercambiado entre sí elementos a través de regiones de clima más fresco.

Sharp (en prensa) cree que las relaciones florísticas entre México y el este de Asia son más significativas que las existentes entre el este norteamericano y esta última región. Además de fanerógamas, cita numerosos helechos y briofitas comunes a ambas zonas y comprueba que muchos de ellos son conocidos del registro fósil de Norteamérica. Sharp expresa la opinión que una gran parte de la flora mexicana actual, tuvo su origen en Asia y en Norteamérica boreal. Los linajes asiáticos deben haber llegado a través de Alaska en el Cretácico y en el Terciario. Posteriormente desaparecieron en muchas partes de Norteamérica debido a los cambios climáticos del Cenozoico superior y del Pleistoceno. La misma idea se expresa en un resumen publicado recientemente (Sharp, 1961).

\section{Relaciones con Africa}

Hemsley (op. cit. vol. IV : 230-232) presenta una lista de 96 géneros comunes entre Africa y la región mexicano-centroamericana. De ellos 39 están representados en ambas zonas por especies idénticas y 69 no se conocen de otros continentes. En el caso de las primeras Hemsley supone que se trata de una introducción relativamente reciente a través de semillas transportadas por corrientes marinas, balasto o actividades humanas. Los linajes restantes datan probablemente de tiempos más re. motos y paralelizan las afinidades africano-americanas en el reino animal. 
Engler (1914: 619-620) refiere la existencia de géneros comunes entre las floras de las regiones áridas de Norteamérica y del norte y sur de Africa y señala la posibilidad de que al menos los grupos xerófitos existentes en la región mediterránea pudieron haber migrado a través del puente noratlántico entre Europa y Norteamérica.

Miranda (1960b) encuentra un importante porcentaje de géneros comunes con Africa en la flora del sureste de México, especialmente en las partes bajas y zonas inundables de la última región. Se trata casi en su totalidad de elementos que también existen en Sudamérica y cuya distribución bicontinental fue estudiada por Engler (1905).

Miranda (op. cit.: 130-131) cree que no hay pruebas suficientes de la existencia de una vía de dispersión a través del Atlántico central y se inclina a considerar que la distribución actual parece ser la consecuencia de la restricción de un área geográfica más amplia que caracterizaba a estos elementos en otras épocas.

\section{MEXICO COMO CENTRO DE ORIGEN Y DE DIVERSIFICACION DE FLORAS}

Muchos autores han postulado la importancia de México como centro de evolución y de dispersión de plantas. Rzedowski (1961: 90-92) cree que estos procesos evolutivos deben haber sido favorecidos a través de cambios climáticos acompañados de cambios fisiográficos ocurridos en el Terciario y en el Cuaternario. Existen numerosas pruebas que México ha sido el teatro de importantes migraciones de floras y faunas, especialmente en los sentidos N-S y S-N. La aparición y la desaparición de, comunicaciones continentales con Centroamérica, Sudamérica y las Antillas, la formación de montañas, altiplanicies, depresiones y de otros rasgos fisiográficos, y los cambios climáticos acompañantes creaban además con frecuencia condiciones propicias para el origen de grupos y linajes de plantas capaces de poblar habitats nuevos, dada la ausencia momentánea de organismos adaptados o preadaptados a tales ambientes.

Una de las pruebas más palpables de la importancia de México como centro evolutivo de plantas constituyen las estadísticas de Bentham (op. cit: 517) relativas a la distribución geográfica de los miembros de la familia Compositae, la más numerosa en géneros y especies dentro de las Fanerógamas.

De acuerdo con Bentham se contaban para México 246 géneros y 1330 especies de Compuestas, números que no alcanza ninguna otra región del continente americano. Los 246 géneros constituyen más del $55 \%$ de todos los conocidos en América, siendo casi la mitad de ellos endémicos y la cuarta parte monotípicos.

\section{A. Plantas de clima árido}

Hemsley (op. cit. vol. IV: 309-310, 315) parece haber sido el primero en definir la parte septentrional de México como el centro de origen de una flora xerófila 
que más tarde se extendió hacia el sur y hacia el norte, aunque Gray y Hooker (1880: 62) y Engler (1882: 217-218) hablan ya de un elemento mexicano en la composición de la flora norteamericana, y Gray (1884: 340) sugiere que muchas de las plantas del suroeste de los Estados Unidos tienen su origen en la vegetación del norte de México.

Schumann (op. cit.: 21), Berger (1915: 8), Ramírez Laguna (1936), Bravo (op. cit.: 67) y otros taxónomos, al revisar diversos grupos de plantas y su distribución, confirman el punto de vista de Hemsley, pues encuentran que el norte de México fue el lugar en donde evolucionaron y se diversificaron muchos géneros ve. getales característicos de clima árido.

Los autores que analizan las relaciones geográficas y los orígenes de la flora de diferentes regiones del suroeste de los Estados Unidos (Harshberger, op. cit.: 244; Abrams, 1925; Kearney y Peebles, 1942: 8-9; Campbell y Wiggins, 1947; Benson, 1957: 617, y otros) coinciden en puntualizar las afinidades mexicanas de una gran parte, por lo menos, de la flora xerófila de esa zona.

Clements (1936: 128) cree que las especies de Gramíneas de talla modesta ("short grasses") características del suroeste norteamericano (Bouteloua gracilis, B. racemosa, Buchloe dactyloides, Aristida spp.) se originaron en las altiplanicies de México.

Shreve (1937b: 611) señala que muchas de las especies de arbustos y árboles del Desierto Sonorense pertenecen a géneros bien representados en el bosque espinoso de la costa de Sinaloa y probablemente se han originado a partir de elementos de este último. Otras especies de Sonora parecen haber evolucionado en el desierto mismo.

En otra publicación (Shreve, 1942: 244) el mismo autor cree que en la flora de los desiertos norteamericanos hay un pequeño grupo de linajes antiguos, origins. dos probablemente en el mismo desierto, y otro grupo más numeroso de elementos provenientes de las partes áridas y semiáridas del sur de México. El grupo más antiguo está mejor representado en la parte norte de los desiertos Chihuahuense y Sonorense, mientras que el elemento más moderno prevalece en la parte sur de las mencionadas áreas.

Epling y Harlan (op. cit.) consideran que los componentes florísticos del chaparral y del matorral de Artemisia tridentata (sagebrush) de la costa de California y del extremo boreal de Baja California tienen su origen en la flora del norte de México.

Rzedowski (1961: 84-85) observa que en la composición de la flora xerófila de San Luis Potosí, además de géneros que parecen haber evolucionado en México y de los que señalan relaciones con Sudamérica, existen otros comunes con las zonas áridas de diversos continentes y un grupo de géneros de distribución geográfica diversa, pero de afinidades más bien mesofíticas, que presentan una o unas pocas especies adaptadas a la aridez. Las especies de estas dos últimas categorías en cai tơdos los casos están retringidas a las regiones secas de México. 
Clements (op. cit.) y posteriormente Cain (1951: 145-150), basándose en la distribución de la vegetación actual del suroeste norteamericano, en las reliquias de comunidades mesofíticas encontradas en el medio desértico y en algunos datos paleontológicos, intentan una reconstrucción paleoecológica de las áreas ocupadas actualmente por la vegetación de tipo desértico. De acuerdo con su interpretación, en el Terciario Inferior la zona fue ocupada por bosques mesófilos más o menos termófilos, pero a partir de esa época el clima se ha ido enfriando y volviendo cada vez más seco, con lo cual la pradera y el chaparral ocuparon paulatinamente sus lugares; estos tipos tuvieron su época óptima en el Plioceno. A fines de ese último período el clima llegó a ser tan árido que la pradera fue substituida por el matorral desértico mediante la evolución de endemismos y la inmigración de especies mexicano-sonorenses, donde el clima y la flora de tipo desértico ya existían con anterioridad. En el Pleistoceno los cambios ocurridos en los períodos glaciales e interglaciales deben haber estado modificando en forma alternativa las áreas respectivas de la pradera y del desierto.

Axelrod (1950) lleva adelante y modifica las ideas de Clements a la luz de numerosos hallazgos paleobotánicos en el oeste norteamericano, haciendo intervenir, además, sus hipótesis propias. Este autor cree que los desiertos constituyen un rasgo climático y fisiográfico relativamente moderno en la superficie de la Tierra, pues se originaron en el Plioceno en regiones que anteriormente eran más húmedas. Paralelamente las plantas xerófilas han ido evolucionando en esos sitios a partir de antecesores mesófilos preexistentes en el área. En el suroeste norteamericano la flora desértica actual también debe haber evolucionado in situ a partir de predecesores de tipo tropical que ocupaban entonces la región, y por consiguiente no es necesario postular un origen mexicano de sus componentes.

Las mencionadas opiniones no son en realidad sino un corolario avanzado por Axelrod de las ideas de la escuela paleobotánica californiana, acerca de la evolución de la que denominan "Geoflora Madro-Terciaria" en el oeste norteamericano. Los numerosos trabajos sobre este tópico se hallan resumidos en la reciente publicación de Axelrod (1958). Se ha considerado conveniente incluir este tema en la presente revisión, pues muchos de los puntos tratados están íntimamente ligados con los orígenes y la evolución de la flora de México, especialmente de la de sus partes áridas y semiáridas.

La "Geoflora Madro-Terciaria" está formada por un conjunto de plantas conocidas por sus restos fósiles, que de acuerdo con los mencionados autores, han evolucionado en el Terciario en el suroeste de los Estados Unidos y en el norte de México como respuesta a la extensión paulatina del clima árido. A fines del Cretácico y a principios del Cenozoico, como se cree, esta región era plana y su clima subtropical a templado-cálido y semihúmedo, con una vegetación de sabana y flora de afinidad neotropical. A partir de aquella época y en función de la disminución de la humedad y de la temperatura la mencionada flora va siendo substituida por otra - la Madro-Terciaria - que evoluciona a sus expensas. En la composición de la flora Madro-Terciaria se encuentran linajes de franca derivación neotropical al lado de otros aparentemente ligados con grupos holárticos, pero Axelrod cree que estos 
últimos también tienen un antiguo origen tropical y formaban parte de la "Geoflora Neotropical Terciaria". En el Terciario Medio la flora Madro-Terciaria se expandió sobre grandes extensiones del oeste norteamericano para irse diferenciando pos. teriormente en diversos conjuntos de vegetación, como el bosque espaciado (wood. land), el chaparral, el matorral espinoso y el desierto. El desierto fue el último en individualizarse, habiéndose derivado sus componentes a partir de plantas que antes habían dominado en las zonas bajas (fig. 6).

Un punto de vista diferenie es el de Herzfeld (1956). Basándose en la idea de Schwarzbach (1950) de que en el Terciario Inferior las zonas climáticas del Hemisferio Boreal estaban desplazadas 10 a $15^{\circ}$ hacia el norte, el mencionado autor cree que en esa época México estaba cubierto por bosques subtropicales y la zona seca se localizaba en el centro de lo que hoy son los Estados Unidos. Sólo a partir del Plioceno medio alcanzaron las regiones áridas su situación y extensión actual. Las xerófitas norteamericanas (Herzfeld discute exclusivamente el caso de las Cactaceae), por consiguiente, deben haber pasado su primer período de evolución mucho más al norte, de donde emigraron a fines del Cenozoico para llegar al territorio que modernamente ocupan.

Grant (1959: 224) considera que los hechos conocidos sólo permiten suponer que el elemento florístico Madro-Terciario se originó en una o en varias áreas caracterizadas por un clima semejante al que prevalece actualmente en el norte de México. El centro (o los centros) de origen de esta flora, sin embargo, pudo haberse localizado dentro o fuera de México.

\section{B) Plantas de clima templado y frío}

Según Hemsley (op. cit. vol. IV: 298-299, 312) la flora característica de las zonas de clima templado y frío de la mitad meridional de México posee afinidadę mixtas, interviniendo principalmente el elemento boreal y el andino, pero casi siempre a nivel genérico, pues las especies en su gran mayoría son locales. Hemsley calcula sólo en $5 \%$ el número de géneros endémicos de esa zona, en cambio las especies de distribución restringida forman el $85 \%$ del número total.

Standley (1936: 13) considera, en cambio, que la flora de las montañas me. xicanas es muy distinta de la de las Montañas Rocallosas, pues está caracterizada por muchos géneros de distribución local. El mismo autor (loc. cit.) señala que en México se localiza el centro de distribución o de variación de las especies de en. cinos (Quercus).

McVaugh (1952, véase cap. IV), a base de estudios taxonómico-filogenéticos, llega a la conclusión que varios grupos de plantas de clima templado han tenido su centro de diversificación en el sur de México, de donde posteriormente se dispersaron hacia el norte a lo largo de las Sierras Madres.

Sharp (1953a: 376-377), tomando como criterio la afinidad a nivel de la familia cree que la flora de clima templado de México es pobre en comparación con la flora tropical y sugiere que ello puede deberse a la circunstancia que en este país 
sólo muy recientemente y a raíz de la elevación de la Altiplanicie se han creado las condiciones necesarias para la inmigración de la primera.

Polemizando con la opinión anterior Martin (1958: 13-14) indica que la Altiplanicie de México se considera como un centro importante de evolución de biota de tipo templado. Cita diferentes tipos de vertebrados endémicos y otros cuya área de diversificación se localiza en el Altiplano. Llama asimismo la atención sobre el hecho que el gran número de especies mexicanas de los géneros Quercus y Pinus, en su mayoría confinadas a las partes altas del país, sugiere la existencia de un importante centro de radiación evolutiva.

Rzedowski (1961: 84-85) señala que además de Quercus y Pinus existen muchos otros géneros con un gran número de especies distribuidas en las áreas de clima templado de México y la flora correspondiente no debe considerarse como pobre. La acentuada diversidad a nivel específico está quizás relacionada con ła existencia de numerosas serranías aisladas, situación que tal vez ha prevalecido en México antes del levantamiento del Altiplano y existe aún actualmente en varias partes del país. Algunos de estos géneros parecen ser de derivación sudamericana y tienen en México un centro secundario de dispersión, como por ejemplo Stevia (Robinson, 1930a: 45; 1930b: 90), Perezia (Bacigalupi, 1931: 10-12), etc.

Maysilles (op. cit.: 118) y Rzedowski en el mismo trabajo (op. cit.: 81-82) presentan listas de plantas que crecen en la zona de clima templado de los Estados de Durango y San Luis Potosí, pertenecientes a géneros restringidos a México o cuyo centro de distribución parece ser México. Es significativo, sin embargo, que la gran mayoría de estas plantas ocupa habitats más bien semi-áridos.

En contraste con lo anterior cabe recordar que una gran parte de los componentes de afinidad boreal de los bosques muy húmedos de la Sierra Madre Oriental y de las sierras de Chiapas (Miranda y Sharp, op. cit.) ni siquiera han evolucionado a nivel específico, pues se trata de las mismas especies que existen en el sureste de los Estados Unidos.

\section{C) Plantas de clima caliente}

La flora de las partes calientes de México es de extracción netamente neotropical y en general parece haberse diferenciado relativamente poco a partir de los prototipos de afinidad meridional. La situación varía, sin embargo, de un lugar a otro, en función principalmente del grado de humedad, pues a semejanza de la flora de las áreas de clima templado y frío, a medida de ser más seco el clima cobran más importancia los taxa endémicos.

De los trabajos de Miranda (1952, vol. 1: 21-41) y de Rzedowski (en prensa) puede deducirse que la zona cálida lluviosa de México contiene muy pocas especies de área de distribución restringida, pues casi todas se extienden a Centroamérica y muchas también a Sudamérica.

Una situación algo distinta se presenta en la Península de Yucatán, donde interviene un número importante de endemismos a nivel específico y aparentemente 
unos cuantos de orden genérico (véanse diversos autores en la discusión de las afinidades florísticas de la Península, cap. III, inciso O).

Este fenómeno es también acentuado en la región caliente menos húmeda a semiárida del noreste de México, donde según Rzedowski (1961: 77.78) las especies locales son abundantes y características.

Tanto Gentry (1946: 461), como Miranda (1947: 96), White (op. cit.: 256) y McVaugh (1961: 146) señalan la gran importancia del elemento endémico en la zona tropical semihúmeda a semiseca de la vertiente pacífica de México.

Una parte de los componentes de la flora del sureste de los Estados Unidos se considera como "tropical" en sus afinidades geográficas y varios autores han pos. tulado el origen mexicano de algunos de estos elementos. Pueden mencionarse a este respecto los trabajos de Schornherst (1943: 525) y de McVaugh (1943: 140. 144), con la salvedad de que en la mayoría de log casos no se trata de plantas de clima caliente en el sentido empleado en este trabajo.

\section{REGIONES FLORISTICAS DE MEXICO}

Desde que Hemsley (op. cit. vol. IV: 223) caracterizó en el país una región florística boreal y otra meridional, poca atención ha recibido en la literatura la idea de detallar en forma más precisa la división de México en provincias definidas por su flora. Numerosas contribuciones, sin embargo, han echado cierta luz sobre el problema; además de las ya referidas en los párrafos anteriores parece interesante mencionar algunas que pueden agruparse bajo los siguientes encabezados:

\section{A) México en las divisiones fitogeográficas del globo}

Los diversos autores que han tratado de dividir la Tierra en provincias florísticas han diferido bastante en su manera de considerar a México. Muchos de estos trabajos no se basan exclusivamente sobre la flora, sino toman en cuenta también la vegetación. A continuación se presentan algunos ejemplos para ilustrar esta di. vergencia de opiniones.

Schouw (1823) parece incluir partes de México en dos de sus 25 reinos: el de las montañas de México y el de las Cactaceae y Piperaceae, que abarca Centroamérica y norte de Sudamérica.

Engler (1909: 226) distingue en México dos regiones, ambas pertenecientes al reino florístico centro-sudamericano:

Región xerofítica mesoamericana con:

Región de América tropical. Provincia de Centroamérica tropical y de California meridional, con:
S Provincia Sonorense

\{ Provincia del Altiplano de México

Zona del sur de California

Zona mexicana

Zona yucateca 


\section{RZEDOWSKI, J., RELACIONES Y ORIGENES DE LA FLORA MEXICANA}

Hayek (1926: 324-325) reconoce en México las siguientes provincias floristicas:

a. Distrito de los bosques de la Sierra Madre,

b. Distrito de los bosques de la Cordillera mexicana,

c. Distrito de la flora de las altas montañas de la Cordillera mexicana, todas pertenecientes a la región florística norteamericana del Pacífico;

d. Distrito de estepa desértica de Sonora y Baja California,

e. Distrito del desierto mexicano, pertenecientes a la región xerofítica centroamericana;

f. Distrito mexicano del Golfo,

g. Distrito costero del oeste de México (jalisciense), pertenecientes a la provincia caríbea de la región florística americana tropical.

La primera región forma parte del reino holártico, las dos últimas, en cambio, se adscriben al reino neotropical.

Good (1953: 29-30, lámina 4) divide el país en dos distritos: lo. de las partes altas de México, perteneciente a la región Pacífica Norteamericana del Reino Boreal, y 20. de las partes bajas y de la costa de México, perteneciente a la región Caríbea del Reino Neotropical.

Schmithüsen (1961: 24) reconoce una sola región bajo-californiano-mexicana, perteneciente al reino florístico neotropical.

\section{B) Problema del límite entre las regiones holártica y neotropical}

México se encuentra en la zona limítrofe entre las regiones holártica y neotropical de la biogeografía clásica. Como es normal en tales casos, extensas áreas presentan una mezcla de elementos florísticos de ambas procedencias o afinidades, en proporciones muy diversas. La Altiplanicie y otras partes de México son los mejores eiemplos de esta situación, en que se dificulta sobremanera trazar un límite preciso. El problema se complica debido a la topografía escarpada del país, a la presencia de numerosos elementos de origen autóctono, a los elementos de afinidad andina y al conocimiento incompleto de la flora y de las áreas de distribución de las especies.

Las siguientes han sido las interpretaciones más sohresalientes de esta cues. tión (fig. 7) :

Engler (1909: 226), Diels (1945: 163) y Emberger (1944: 462) consideran todo el territorio mexicano como parte del reino neotropical.

Hayek (1926, mapa) incluye la mayor parte de México en el reino neotropical. dejando a la zona holártica las Sierra Madre Occidental, Oriental. del Sur y el Eje 
Volcánico Transversal, las tres últimas en forma de islotes desconectados del área continua de la Holarctis.

Good (op. cit.: lámina 4) y Gaussen (1954: 187) pasan la línea de demarcación de tal manera que todo el Altiplano, las tres Sierras Madres y la mitad norte de $(0$ toda) Baja California forman parte del reino holártico, mientras que el resto del país pasa a ser neotropical.

Vivó (1943: 111-112) señala como límite sur de la región fitogeográfica neártica una línea que parte de ambas costas al nivel del trópico y que corre a lo largo de la cota de $2000 \mathrm{~m}$ sobre el borde exterior de las Sierras Madres y de la Cordillera Volcánica. El límite norte de la región fitogeográfica neotropical se sitúa a través de la Depresión de Nicaragua. Toda el área comprendida entre estas dos líneas se considera como una zona fitogeográfica de transición, con características inter. medias.

\section{C) Zonas de vegetación}

La distribución de las zonas de vegetación de México guarda indudablements muchas relaciones con la de las regiones florísticas. Sobre el primer tópico existen en la literatura numerosos trabajos; entre los que se refieren a todo el país merecen mencionarse: Martens y Galeotti (1842), Richard y Galeotti (1844), Fournier (1878b), Ramírez (1899), Sanders (1921), Nelson y Goldman (1926), Ochoterena (1918, 1937, 1945), Contreras Arias (1942), Leopold (1950), Miranda y Heinández X. (1959), Gómez Pompa (1961).

Además, pueden encontrarse contribuciones interesantes en diversos trabajos sobre la vegetación del mundo, de América del Norte o de América Latina, como por ejemplo los de Grisebach (1878: 459-499), Drude (1890: 445-446; 503-509). Harshberger (1910: 634-668), Hardy (1920: 80, 115-123), Brockman-Jerosch (1930), Smith y Johnston (1945), Küchler (1960), etc.

\section{D) Provincias bióticas de los zoólogos}

De acuerdo con el criterio de Vestal (1914: 432) la provincia hiótica se define a través de la similitud de áreas de distribución de plantas así como de animales eco. lógicamente afines.

Aunque esencialmente fundamentadas sobre bases faunístico-ecológicas, las provincias bióticas, sus extensiones y sus límites mucho tienen en común con las áreas florísticas, y puesto que existe bastante literatura relativa a la distribución de las primeras en México, se ha creído conveniente incluir algunos de estos datos en la presente revisión bibliográfica.

Dice (1943), en si monografía clásica sobre las provincias bióticas de Norteamérica, incluye el norte de México, donde distingue 10 unidades, de las cuales la más grande es la Chihuahuense, que abarca la mayor parte de la Altiplanicie. 

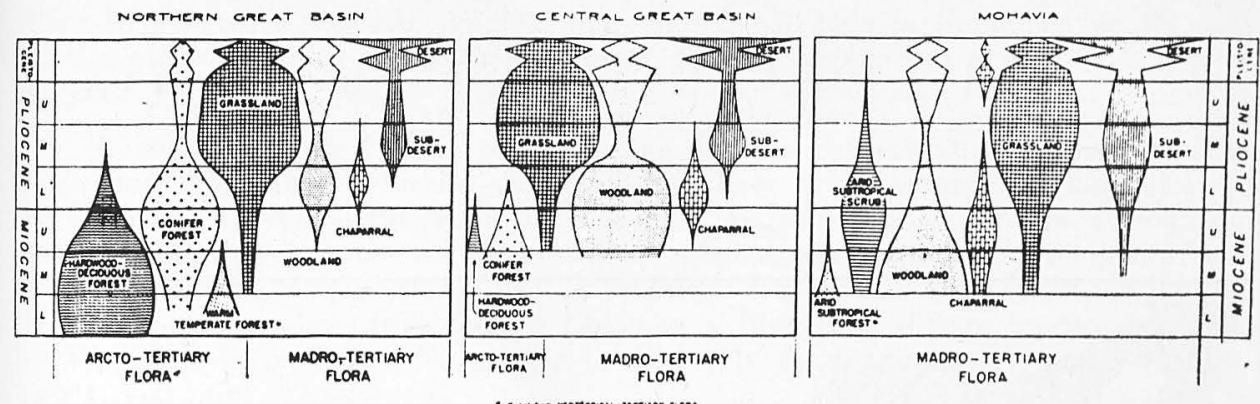

Fig. 6 Cambios de tipos de vegetación en la actual región desértica durante el Cenozoico medio y superior, según Axelrod, 1950.

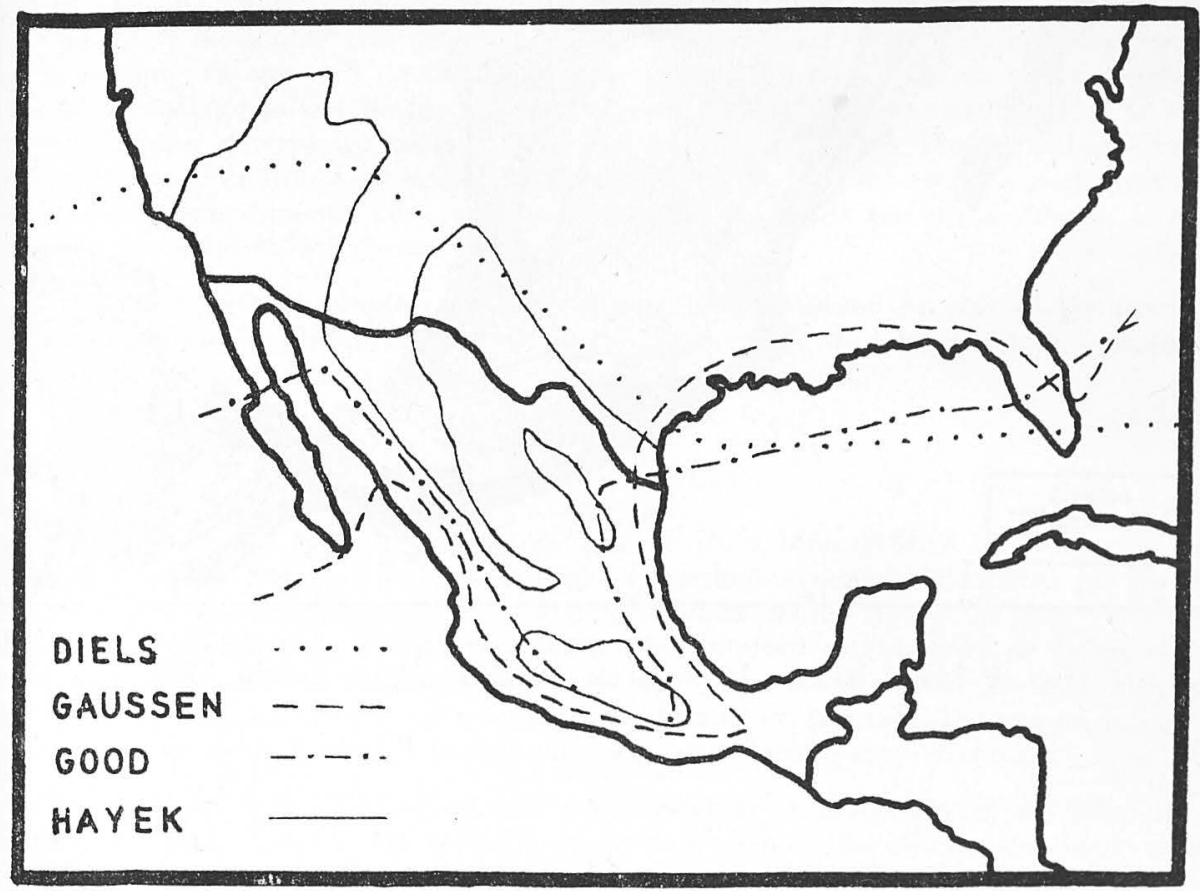

Fig. 7 Interpretación del límite entre las regiones florísticas holártica y neotropical, según algunos autores (dibuịo de Graciela C. de Rzedowski). 


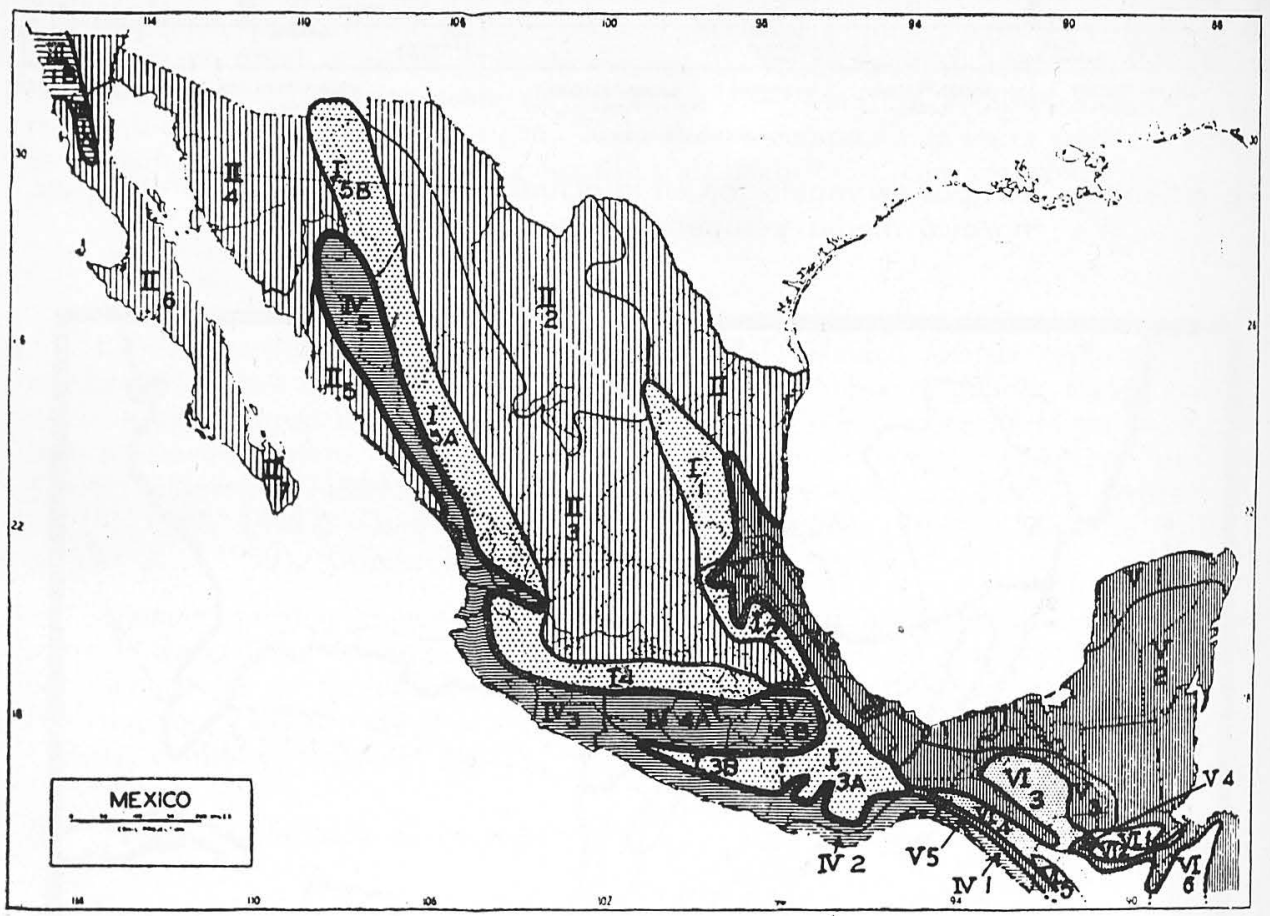

Fig. 8 Subdivisiones bióticas de México, según Smith, 1959. 
H.M. Smith (1940: mapa), basándose en la distribución geográfica de las lagartijas del género Sceloporus, propone una división de toda la República en 23 provincias bióticas, de las cuales 16 pertenecen a la región neártica y el resto a la neotropical. .

Goldman y Moore (1945) proponen una división del país en 18 provincias bióticas, que son "áreas naturales distinguidas a base de agrupamientos naturales de las especies con consideración a las relaciones bióticas y a la historia geológica". De hecho las descripciones de los autores se refieren principalmente a los mamíferos y a las aves, incluyendo datos sobre el ambiente físico y las plantas. En principio la delimitación de las provincias de Goldman y Moore no difiere mucho de la de Smith, siendo la principal divergencia la distinción de una unidad grande: la Provincia Volcánica Transversal.

El mapa de Osorio-Tafall (1949) no incluye más que leves modificaciones con respecto al de Goldman y Moore.

En un trabajo más reciente Smith (1949) presenta un mapa con más innovaciones (fig. 8). Incluyendo Guatemala describe 31 provincias bióticas, mismas que agrupa en 6 conjuntos más grandes - subregiones - de las cuales 3 forman parte de la región neártica y 3 de la región neotropical. La distinción de subregiones da una idea bastante buena de las relaciones entre las diferentes provincias, así la subregión serrana incluye las Sierras Madres y el Eje Volcánico Transversal, la Sonorense abarca el conjunto de zonas áridas del norte de México, etc. La nomenclatura difiere, desgraciadamente, casi por completo de la empleada por otros autores, lo que dificulta un poco la interpretación.

Bourliére (1964) emplea un criterio semejante, aunque no usa el término de provincias bióticas. Divide el país en 5 zonas (desértica, de altas montañas, de transición, tropical atlántica y tropical pacífica) y 16 regiones.

\section{RESUMEN Y CONCLUSIONES}

1. El presente trabajo consiste de una revisión bibliográfica de lo que se ha escrito acerca de las relaciones geográficas y posibles orígenes de la flora de México. Esta flora es particularmente rica y diversificada debido a: 1o. la gran variedad de condiciones climáticas y fisiográficas; 2o. las intensas migraciones de floras efectuadas en el pasado en el territorio del país; 3o. la circunstancia de que México ha sido un centro importante de evolución de linajes de plantas; 4o. que en la composición de la flora intervienen elementos de procedencia muy diversa.

2. Se debe a Hemsley el estudio más completo y exhaustivo de las relaciones geográficas de la flora de México. En su trabajo se han discutido o señalado prácticamente todos los aspectos importantes del problema y muchas de las conclusiones de la obra están tan bien fundadas y desarrolladas que difícilmente podrán ser superadas algún día. Es por loutanto aún más notable la escasa atención que la mayoría de los autores modernos le prestan a la meritoria obra de Hemsley, que a pesar 
de haber transcurrido más de 70 años de la fecha de su publicación sigue siendo básica para los estudios de relaciones florísticas de México.

Desde Hemsley se reconocen los hechos de primordial importancia de las relaciones meridionales y de las boreales. Entre las meridionales se distinguen las existentes con las zonas amazónica y andina; se señala la semejanza de la flora del sur de México con la de Centroamérica y las discrepancias con la de las Antillas. Entre las relaciones boreales se distinguen también las propias con el este y con el oeste de Norteamérica. Se reconoce asimismo la importancia del norte de México como centro de evolución de numerosas plantas xerófilas.

3. De las contribuciones más importantes logradas después del trabajo de Hemsley pueden citarse las siguientes:

a) caracterización florística de las Penínsulas de Yucatán y de Baja California, que representan territorios fitogeográficos con rasgos algo diferentes del resto del país;

b) discusión sobre el posible significado de linajes comunes entre las regiones áridas de Norte y Sudamérica, separadas por un amplio cinturón de selvas ecuatoriales;

c) definición y discusión acerca del posible significado de las relaciones entre la flora de ciertas regiones húmedas templadas del este de México y la del este de los Estados Unidos, separadas actualmente por una faja de clima árido;

d) interpretación a base de datos paleontológicos de los cambios florísticos y cli. máticos ocurridos en el suroeste de los Estados Unidos, especialmente en cuanto a los climas áridos y a la forma en que se ha ido originando la flora xerófila.

4. De todos los estudios realizados sólo una pequeña fracción toma en cuenta datos derivados del registro fósil, circunstancia que se explica hasta cierto punto dada la escasez de conocimientos en este campo. A la luz de lo anterior puede com. prenderse que los hechos de distribución de plantas vivientes han constituido hasta ahora prácticamente la única base para todo tipo de deducciones relativas a las afi. nidades y a los orígenes de la flora. En cuanto a las afinidades, puede decirse, que a pesar de las grandes deficiencias de conocimiento de la flora del país, especial. mente de algunas de sus regiones, y a pesar de las discrepancias entre diferentes autores, se ha podido establecer una serie de conceptos firmes y hechos indiscutibles. En lo que concierne, en cambio, al problema de los orígenes, a falta de comproba. ción paleontológica, la generalidad de las conclusiones no pasan mucho más allá del terreno de las hipótesis.

Para asegurar bases más firmes a los adelantos en el campo de la fitogeografía de México es indispensable en el momento actual iniciar un estudio intensivo de plantas fósiles, principalmente del Terciario continental, pues sólo así podrá adqui. rirse una idea más precisa acerca de la historia de la flora y de la vegetación del país, acerca de sus orígenes y migraciones, y acerca de los ambientes en que vivieron. 
Otro requisito indispensable para llevar a cabo este adelanto será una estrecha colaboración entre los paleobotánicos y los fitogeógrafos en el momento de la interpretación de los datos, pues la experiencia ha demostrado que algunas de las deducciones realizadas por los paleontólogos han adolecido de serios errores debidos a su incompletò conocimiento de la vegetación actual, al igual que las contribuciones de los fitogeógrafos que ignoraban los datos geológicos y paleobotánicos.

5. Si bien sería muy de desearse la existencia de conocimientos paleobotánicos y paleoecológicos, necesarios para la interpretación correcta de los problemas del origen de las floras, estos conocimientos siempre deberán estar acompañados de los datos obtenidos mediante análisis florísticos y los unos tendrán que complementar a los otros.

Por consiguiente, es de recomendarse que las investigaciones fitogeográficas de México, que tanto auge han cobrado en los últimos años, continúen al mismo ritmo ascendente, que vaya ampliándose su radio de acción, que vaya profundizándose el ataque de los problemas y que vayan depurándose los métodos de trabajo.

En los incisos siguientes se señalan algunos aspectos de la fitogeografía de México que, en opinión del autor, sería conveniente abordar en el futuro próximo.

6. Entre los análisis de las afinidades florísticas hasta ahora realizados prevalecen cuali y cuantitativamente los relativos a las relaciones boreales, que son por consiguiente las mejor conocidas en el momento actual. Sería de desearse que esta situación se remediase a través de estudios futuros, puesto que el elemento meridional es el más importante en la flora de México y su complejidad es bastante considerable.

7. En cuanto a los estudios de tipo regional la situación actual es muy dispareja. Algunas zonas como: Baja California, Chiapas, San Luis Potosí y Península de Yucatán, han sido estudiadas en forma intensiva. De otras partes se tiene un conocimiento parcial o incompleto, y quedan aún regiones, como por ejemplo casi todo Veracruz, Oaxaca, Tabasco, Hidalgo, Querétaro, Guanajuato, Aguascalientes, de las que no hay aparentemente mención alguna en la literatura y que merecen ser tomadadas en cuenta en las investigaciones ulteriores.

De los estudios de tipo regional ha surgido una serie de interesantes problemas fitogeográficos locales, en los cuales intervienen indudablemente diversos factores hisjricos y que constituyen temas atractivos para trabajos futuros.

8. Aunque existen en la literatura menciones de provincias florísticas "veracruzana", "tamaulipeca", "yucateca", etc., así como delimitaciones de regiones florísticas dentro de algunos estados, falta un estudio moderno integral tendiente a distinguir, caracterizar y delimitar las zonas florísticas de México. La realización de tal estudio tropezaría con la dificultad de un conocimiento desigual de la flora de las diferentes regiones del país, pero indudablemente las condiciones son lo suficientemente maduras para adelantar por lo menos un esquema tentativo que pudiera servir como hipótesis de trabajo, a semejanza de como lo han hecho los zoólogos. 
Un corolario de lo anterior sería la tentativa de una determinación de los lí. mites entre los reinos florísticos holártico y neotropical en México. Sería interesante averiguar si es factible precisar líneas fronterizas exactas, si solamente se pueden señalar franjas de transición, si todo México debe considerarse como una zona de transición, o si el límite se halla desplazado más al norte de las fronteras con los istados Unidos.

9. Han sido relativamente pocos los intentos de correlacionar los conocimientos fitogeográficos con los zoogeográficos en México. Los resultados de estas com. paraciones han demostrado que, si bien hay muchos paralelismos entre la distribución de las plantas y de los animales, por otra parte pueden observarse algunas dis. crepancias notables, al menos entre las fanerógamas y los vertebrados.

Parecería muy recomendable una mayor coordinación de trabajos entre los fito. geógrafos y los zoogeógrafos, de cuyo esfuerzo conjunto podrían obtenerse muy ve. rosímilmente resultados por demás interesantes.

\section{SUMMARY AND CONCLUSIONS}

1. The author attempts a bibliographic revision of what has been written on the subject of geographical relationships and possible origins of the flora of Mexico. This flora is particularly rich and diversified due to: a) a great variety of climatic and physiographic conditions; h) the intense migrations of floras which took place in the past over the territory of the country; c) the fact that Mexico was an important centre of evolution of plant lineages; d) a very diverse origin of its components.

2. Hemsley elaborated the most complete and exhaustive study of the geographical relationships of the Mexican flora ever made. In his work practically all im. portant aspects of the involved problem are shown and discussed. Many of the conclusions are very well founded and it will be difficult to excel or improve them at any time. Consequentially, it is not easy to explain why most of the modern authors pay so little attention to the meritorious contribution of Hemsley, which, in spite of having been published more than 70 years ago, continues being basic in the studies of floristic relationships of Mexico.

Hemsley recognized the most important facts of southern and northern relations. Among the southern affinities those with Amazonian and Andean regions are distin. guished. Similarities between the flora of southern Mexico and that of Central Amer. ica as well as differences with the Antillean flora are emphasized. Among the northern affinities Hemsley differentiated those with eastern and western North America. Northern Mexico is recognized as an important evolutionary centre of a large number of xerophilous plants.

3. The following are the most important contributions attained since Hemsley's work: 
a) floristic characterization of the peninsulas of Yucatan and of Baja California, phytogeographic territories with peculiar differencial features;

b) discussions of the possible significance of lineages common to North and South American arid zones, which are separated from each other by means of a wide belt of equatorial forests;

c) definition and discussion of the possible significance of floristic relationships between certain humid temperate regions of eastern Mexico and eastern United States, separated at present by a belt or arid climate;

d) interpretation of floristic and climatic changes which ocurred in southwestern United States, based on paleontological data, especially in connection with arid climate and with the origin of the xerophilous flora.

4. Among the studies realized only a small number uses fossil record evidences, and this circumstance is due to the very limited knowledge in the field of the paleobotany of Mexico. Thus it can be understood that so far the facts of geographical distribution of living plants provide practically the only basis for all the deductions concerning the affinities and the origins of the flora. As to the affinities it can he asserted that, in spite of large deficiencies in the knowledge of the flora of the country, especially of some of its regions, and in spite of discrepancies between some authors, it was possible to establish a number of firm concepts and of doubtless facts. As to the problem of the origins, however, in view of the absence of paleontological evidence most of the conclusions have to be considered as hypothetical.

In order to provide a stronger basis for the advancement in the field of phytogeography of Mexico it is indispensable at the present to initiate intensive studies of fossil plants, especially in continental Tertiary deposits. Only by means of such studies will be possible to acquire a more precise idea about the history of the vegetation and of the flora of the country, about their origins and migrations, and about the environments in which they lived.

Another requirement necessary to realize this progress will be a close collaboration between paleobotanists and phytogeographers in the interpretation of the data. Experience has shown that some of the deductions drawn by paleontologists include serious mistakes, due to their incomplete knowledge of the modern vegetation. In a similar way, include serious errors many contributions of phytogeographers who ignored geological and paleontological evidence.

5. In a similar the the existence of paleobotanical and paleoecological evidence is most desirable, in order to interpret in a correct way the problems of origins of floras. These data should be accompanied always by evidence obtained from floristic analysis, and both kind of information should complement each other.

In consequence, it is to be strongly recommended that the phytogeographical studies of Mexico, which progressed rapidly during recent years, should continue at an increased rate, widen their scope, dig deeper in the treatment of the problems, and depurate their methodology. 
In the following paragraphs those aspects of the phytogeography of Mexico are pointed out, for which in the author's opinion, preference should be given in future studies.

6. Among the realized analysis of floristic affinities prevail those dealing with northern relationships, which are the best known at present. It would be desirable to modifiy this situation by means of an increased number of investigations devoted to the southern component which is the most important and complex one in the flora of Mexico.

7. Concerning the studies of regional character the situation is very unequal. Some areas like Baja California, Chiapas, San Luis Potosí and the Peninsula of Yucatan were studied intensively. Other areas are partially or incompletely known and some of these such as most of Veracruz, Oaxaca, Tabasco, Hidalgo, Queretaro, Guanajuato and Aguascalientes, apparently are not mentioned in the floristic literature. They deserve to be considered in future investigations.

From the regional studies a number of interesting local phytogeographical problems became apparent, with diverse historic factors playing undoubtedly an important role.

8. Although the names "tamaulipan". "veracruzian", etc., floristic provinces have been used in literature, and floristic regions have been defined within some states, there is no modern study available attempting to distinguish, characterize and demarcate the floristic regions of Mexico. The elaboration of such as study will be somewhat difficult to accomplish on aecount of the unequal knowledge of the flora of different areas of the country, but certainly the situation is mature enough to advance a tentative scheme which would serve as a working hypothesis, like the one offered by zoologists.

A corollary of the former would be a tentative determination of the limits between the holarctic and the neotropical floristic kingdoms as they occur in Mexico. It would be interesting to know if it is possible to draw exact border lines, if only transition belts can be outlined, if the entire country should be considerde as a transition zone, or if the limit is to be found to the north of the United States-Mexican border.

9. Relatively few authors tried to correlate phytogeographical and zoogeographical evidence in Mexico. The results of these comparisons have shown that, although many common patterns of distribution can be found between plants and animals, a number of noteworthy discrepancies may be observed, at least between the flowering plants and the vertebrates.

A wider coordination of efforts between phytogeographers and zoogeographers is to be recommended. From such a common effort significant results may be expected. 


\section{LITERATURA CITADA}

Abrams, L. R. 1925. The origin and geographical affinities of the flora of California. Ecology 6: $1-6$.

Alain, Hno. 1958. La flora de Cuba, sus principales características, su origen probable. Rev. Soc. Cub. Bot. 15: 36-59; 84-96.

Arldt, T. 1919. Palaeogeographie (citado por Krüger, 1934).

Axelrod, D. I. 1948. Climate and evolution in western North America during Middle Pliocene time. Evolution 2: 127-144.

Axelrod, D. I. 1950. Evolution of desert vegetation in western North America. Carn. Inst. Wash. Publ. 590: 215-306.

Axelrod, D. I. 1958. Evolution of the Madro-Tertiary Geoflora. Bot. Rev. 24: 433-509.

Axelrod, D. I. 1960. The evolution of flowering plants. In: The evolution of life. Its origin, history and future (Evolution after Darwin. The University of Chicago Centennial. Vol. 1). University of Chicago Press. Chicago. Pp. 227-305.

Bacigalupi, R. 1931. A monograph of the genus Perezia, section Acourtia, with a provisional key to the section Euperezia. Contr. Gray Herb. 97: 1-81.

Bader, F. J. W. 1960. Die Verbreitung borealer und subantarktischer Holzgewachse in den Gebirgen des Tropengürtels. Nova Acta Leopoldina. N. f. 23 (148): 1-544.

Bartram, E. B. 1929. Honduran mosses collected by Paul C. Standley. Field Mus. Nat. Hist. Bot. Ser. 4: 349-364.

Bartram, E. B. 1932. Mosses of northern Guatemala and British Honduras. Journ. Wash. Acad. Sci. 22: 476-482.

Benson, L. 1957. Plant classification. D. C. Heath and Company. Boston, Mass. 688 pp.

Bentham, G. 1873. Notes on the classification, history and geographical distribution of the Compositae. Journ. Linn. Soc. London 13, 335-577.

Berger, A. 1915. Die Agaven, Beitrage zu einer Monographie. G. Fischer. Jena. 288 pp.

Bonet, F. y J. Rzedowski. Vegetación del Arrecife Alacranes. Trabajo presentado en el Primer Congreso Mexicano de Botánica (en prensa).

Bourliere, F. 1946. Les grands traits de la biogéographie du Mexique. Bull. Soc. Nat. Accl. Prot. Nat. 33: 1-10.

Brandegee, T. S. 1889. A collection of plants from Baja California. Proc. Calif. Acad. Sci. 2 ser. 2: 117-216.

Brandegee, T. S. 1892. The distributicn of the flora of the Cape region of Baja California. Zoe 3: 223-231.

Brandegee, T. S. 1893. Southern extension of California flora. Zoe 4: 199-210.

Eraun, E. L. 1955. The phytogeography of unglaciated eastern United States and its interpretation. Bot. Rev. 21: 297-375.

Bravo. H. 1937. Las Cactáceas de México. Universidad de México. México, D. F. $755 \mathrm{pp}$.

Bray, W. L. 1898. On the relation of the flora of the Lower Sonoran zone in North America to the flora of the arid zones of Chili and Argentina. Bot. Gaz. 26: 121-147.

Bray, W. L. 1900. The relations of the North American flora to that of South America. Science n.s. 12: 712-716.

Brockman-Jerosch, H. 1930. Formaticnsklassen der Erde (mapa), in: Rübel, E., Pflanzengesellschaften der Erde. H. Huer. Bern. 464 pp.

Cain, S. A. 1951. Fundamentos de fitogeografía. Acme Agency. Buenos Aires. 659 pp. (traducción del original inglés publicado en 1944).

Campbell, D. H. \& I. L. Wiggins. 1947. Origins of the flora of California. Stanford Univ. Publ. Biol. Sci. 10: 1-19.

Cardot, J. 1910. Coup d'oeil sur la flore bryologique du Mexique. Rev. Bryol. 37: $79-84$.

Carlson, M. C. 1954. Floral elements of the pine-oak-Liquidambar forest of Montebello, Chiapas, Mexico. Bull. Torrey Bot. Club 81: 387-400. 
Carter, A., Afinidades florísticas de la Sierra Giganta de Baja California, México. Traba. jo presentado en el Primer Congreso Mexicano de Botánica (en prensa).

Clements, F. E. 1936. The origin of the desert climax and climate, in: Essays in geobotany in honor of William Albert Setchell. Univ. California Press. pp. 87-140.

Contreras Arias, A. 1942. Mapa de las provincias climatológicas de la República Mexicana. Secretaría de Agricultura y Ganadería. México, D. F.

Crum, H. A. 1951. The Appalachian-Ozarkian element in the moss flora of Mexico with a check-list of all known Mexican mosses. Ph. D. thesis. Univ. Michigan. 504 pp.

Dice, L. R. 1943. The biotic provinces of North America. Univ. Michigan Press. Ann Arbor, Mich. 78 pp.

Diels, L. 1945. Pflanzengeographie. Walter de Gruyter \& Co. 4a. edic. Berlin. $167 \mathrm{pp}$.

Dressler, R. L. 1954. Some floristic relationships between Mexico and United States. Rhodora 56: 81-96.

Drude, O. 1890. Handbuch der Pflanzengeographie. Stuttgart.

DuRietz, G. E. 1940. Problems in bipolar plant distributicn. Acta Phytogeogr. Suec. 13: $215-282$.

Eastwcod, A. 1929. Studies in the flora of Lower California and adjacent islands. Proc. Calif. Acad. Sci. 4 ser. 18: 393-484.

Emberger, L. 1944. Les plantes fossiles dans leur rapports avec les végétaux vivants. Mason \& Cie. Paris. 492 pp.

Engler, A. 1882. Versuch einer Entwicklungsgeschichte der Pflanzenwelt, insbesondere der Florengebiete seit der Tertiarperiode. Parte II. Die extratropischen Florengebiete der südlichen Hemisphare und die tropischen Gebiete. W. Engelmann. Leipzig. 386 pp.

Engler, A. 1905. Über floristische Verwandschaft zwischen dem tropischen Afrika und Amerika. Sitzungsber. Konigl. Preuss. Akad. Wiss. 6: 1-52.

Engler, A. 1909. Syllabus der Pflanzenfamilien. 6a. edic. Gebr. Borntrager. Berlin. 254 pp.

Engler, A. 1914. Über Herkunft, Alter und Verbreitung extremer xerothermer Pflanzen. Sitzungsber. Konigl. Preuss. Akad. Wiss. 1914: 564-621.

Epling, C. 1939. A note on the occurrence of Salvia in the New World. Madroño 5: 34-37. 1939.

Epling, C. 1940a. The Labiatae of the Yucatan Peninsula. Carn. Inst. Wash. Publ. 522: $227-245$.

Epling, C. 1940b. The distribution of the American Labiatae. Proc. Sixth Pacif. Sci. Congr. 4: 571-575.

Epling, C. \& L. Harlan. 1942. The centers of distribution of the chaparral and coasta] sage asscciations. Amer. Midl. Nat. 27: 445-462.

Espinosa, G., J. 1961. Vegetación de una corriente de lava de formación reciente localizada en el declive meridional de la Sierra de Chichinautzin. Tesis. Facultad de Ciencias, U.N.A.M. 85 pp.

Fernald, M. L. 1931. Specific segregation and identities in some floras of eastern North America and the old World. Rhodora 33: 25-63.

Foumier, E. 1878a. Sobre la distribución geográfica de Ios helechos en México. La Naturaleza la ser. 4: 82-84 (traducción del artículo publicado en Compt. Rend. Acad. Sci. 68: 1040-1042. 1869).

Fournier, E. 1878b. In: Gisebach, A., La Végétation du globe. Paris. vol. 2. pp. 487-493 (traducido al español en Ramírez, 1899) (publicado también en español bajo el nombre de "Las zonas botánicas de México" en Prcgreso de México 7: 233, 242, 264. 1900).

Fournier, E. 1884. Distribución geográfica de las gramíneas mexicanas. La Naturaleza la ser. 6: 323-343. (traducción del artículo publicado en Ann. Sci. Nat. sér. 6, 9: 261-290. 1878).

Gadow, H. 1907-1909. Altitude and distribution of plants in southern Mexico. Journ. Linn. Soc. Bot. 38: 429-440. 
García E., C. Soto y F. Miranda. 1961. Larrea y clima. An. Inst. Biol. Univ. Méx. 31: 133-171.

Gaussen, H. 1954. Géographie des plantes. 2: edic. Librairie A. Colin. Paris. 224 PI. Gentry, H. S. 1942. A study of the flora and vegetation of the valley of the Rio Mayo, Sonora, Carn. Inst. Wash. Publ. 527: 1-328.

Gentry, H. S. 1946. Notes on the vegetation of Sierra Surotato in northern Sinaloa. Bull. Torrey Bot. Club 73: 451-462.

Gleason, H. A. 1940. The Melastomaceae of Yucatan Peninsula. Carn. Inst. Wash. Publ. 522: 325-373.

Goldman, E. A. \& R. T. Moore. 1945. The biotic provinces of Mexico. Journ. Mamm. 26: 347-360.

Gómez Pompa, A., La vegetación, In: Coloquios sobre el estado actual de los estudios fitogeográficos de México.

Good, R. 1953. The geography of the flowering plants. 2a edic. Longmans, Green \& Co. London. 452 pp.

Grant, V. 1959. Natural history of the Phlox family. Martinus Nijhoff. The Hague. $280 \mathrm{pp}$.

Gray, A. 1878. Forest geography and archaeology. Amer. Journ. Sci. Arts III, 16: 85-94, $183-196$.

Gray, A. 1884. Characteristics of the North American flora. Amer. Journ. Sci. Arts III, 28: 32:3-340.

Gray, A. \& J. D. Hooker. 1880. The vegetation of the Rocky Mountain region, and a comparison with that of other parts of the world. Bull. U. S. Geol. \& Geogr. Surv. 6: 1-77.

Grisebach, A. 1877-1878. La végétation du globe. Librairie J.-B. Bailliére et Fils. Paris. 2 vols.

Hallier, H. 1912. Über frühere Landbrücken, Pflanzen- und Volkerwanderungen zwischen Australasien und Amerika. Meded. Rijks Herb. Leiden 13: 1-32.

Hardy, M. E. 1920. The geography of plants. Oxford University Press. London. $327 \mathrm{pp}$. Harbshbereg, J. W. 1911. Phytogeographical survey of North America. Vegetation der Erde, vol. III. W. Engelmann. Leipzig. $790 \mathrm{pp}$.

Hayek, A. 1926. Allgemeine Pflanzengeographie. Gebr. Borntrager. Berlin. 408 pp.

Heilprinn, A. 1899. Floras de las regiones templadas y alpinas de los grandes volcanes de México. La Naturaleza 2a ser. 3: 233-24:3 (traducción del artículo publicado en Proc. Amer. Phil. Soc. 30: 4-22. 1892).

Hemsley, W. B. 1879-1888. Botany, in: Godwin, F. D. \& O. Salvin, Biologia CentraliAmericana. R. H. Porter. London. 5 vols.

Hernández X., E. 1959. Patrones de distribución de algunos zacates mexicanos. Chapingo 77/78: 392-398.

Hernández, X., E., H. Crum, W. B. Fox \& A. J. Sharp. 1951. A unique vegetational area in Tamaulipas. Bull. Torr. Bot. Club 78: 458-463.

Herrera, A. 1891. El Valle de México considerado como una provincia zoológica. La Naturaleza 2a ser. 1: 343-442.

Herzfeld, F. 1956. Die Verbreitungsgeschichte der nordamerikanischen Echinokakteen. Willdenowia 1: 389-403.

Humboldt, A. \& A. Bonpland. 1805. Essai sur la géographie des plantes, accompagné d’un tableau physique des régions équinoxiales. Paris. $155 \mathrm{pp}$.

Johnston, I. M. 1924. Expedition of the California Academy of Sciences to the Gulf of California in 1921; The botany (The vascular plants). Proc. Calif. Acad. Sci. 4 ser. 12: $951-1218$.

Iohnston, I. M. 1931. The flora of the Revillagigedo Islands. Proc. Calif. Acad. Sci. 4 ser. 20: 9-104. 
Johnston, I. M. 1940. The floristic significance of shrubs common to North and South American deserts. Journ. Arnold Arbor. 21: 356-363 (publicado también en españo] en Rev. Argent. Agron. 8: 114-121. 1941).

Johnston, I. M. 1943. Plants of Coahuila, eastern Chihuahua, adjoining Zacatecas and Durango. I. Journ. Arnold Arbor. 24: 306-339.

Kearney, T. H. \& R. H. Peebles. 1942. Flowering plants and ferns of Arizona. U.S Dept. Agric. Misc. Publ. 423. Washington, D. C. $1069 \mathrm{pp}$.

Kotschy, T. 1852. Überblick der Vegetation Mexiko's. Sitzungsher. Akad. Wiss. Wien 8: $187-195$.

Küchler, A. W. 1960. Generalized land vegetation map of the world, in: Polunin, N., Introduction to plant geography. Longmans. London. $640 \mathrm{pp}$.

Leavenworth, W. C. 1946. A preliminary study of the vegetation of the region between Cerro Tancitaro and the Rio Tepalcatepec, Michoacan, Mexico. Amer. Midl. Nat. 36: $137-206$.

Leopold, A. S. 1950. Vegetation zones of Mexico. Ecology 31: 507-518 (publicado también en español en Bol. Soc. Mex. Geogr. Estad. 73: 47-93. 1952).

Lundell, C. L. 1937. The vegetation of Petén. Carn. Inst. Wash. Public. 478: 1-207.

Martens, M. \& H. Galeotti. 1842. Sur les fcugéres du Mexique et considérations sur la géographie de cette contrée. Mém. Acad. Sci. Brux. 15. (citado y traducido al español, in Ramírez, 1899).

Martin, P. S. 1958. A biogeography of reptiles and amphibians in the Gomez Farias region. Tamaulipas, Mexico. Misc. Publ. Mus. Zool. Univ. Mich. 101: 1-115.

Martin, P. S. \& B. E. Harrell. 1957. The Pleistocene history of temperate biotas in Mexico and eastern United States. Ecology 38: 468-480.

Matuda, E. 1953. Plantas asiáticas en México. Mem. Congr. Cient. Mex. 6: 230-248.

Maysilles, J. H. 1959. Flora relationships of the pine forests of western Durango, Mexico. Ph. D. thesis. Unived. Michigan. 165 pp.

McVaugh, R. 1943. The vegetation of the granitic flat-rocks of the southeastern United States. Ecol. Monogr. 13: 119-166.

McVaugh, R. 1952. Suggested phylogeny of Prunus serotina and other wide-ranging phylads in North America. Brittonia 7: 317-346.

McVaugh, R. 1961. Euphorbiaceae novae Novo-Galicianae. Brittonia 13: 145-205.

Miranda, F. 1943. Estudios sobre la vegetación de México. IV. Algunas características de la vegetación y de la flora en la zona de Acatlán, Puebla. An. Inst. Biol. Univ. Méx. 14: 407-421.

Miranda, F. 1947. Estudios sobre la vegetación de México. V. Rasgos de la vegetación en la cuenca del río de Las Balsas. Rev. Soc. Mex. Hist. Nat. 8: 95-114.

Miranda, F. 1948. Datos sobre la vegetación en la cuenca alta del Papaloapan. An. Inst. Biol. Univ. Méx. 19: 333-364.

Miranda, F. 1952. La vegetación de Chiapas Ediciones del Gobierno del Estado. 2 vols. Tuxtla Gutiérrez, Chis.

Miranda, F. 1957a. Vegetación y ecología, in: Lo que ha sido y lo que puede ser el Sureste vol. 1: 73-103. México, D. F.

Miranda, F. 1957b. Vegetación de la vertiente del Pacífico de la Sierra Madre de Chiapas (México) y sus relaciones florísticas. Proc. Eighth Pacific Sci. Congr. 4: 438-453.

Miranda, F. 1958. Estudios acerca de la vegetación, in: Los recursos naturales del Sureste y su aprovechamiento, vol. 2: 215-271. Ediciones del Inst. Mex. Rec. Nat. Renov. México, D. F.

Miranda, F. 1960a. Vegetación, in: La Isla Socorro. Monografías del Instituto de Geofísica, U.N.A.M. No. 2: 157-152.

Miranda, F. 1960b. Posible significación del porcentaje de géneros bicontinentales en América tropical (Afinidades de la flora arbórea de regiones húmedas del sureste de México). An. Inst. Biol. Univ. Méx. 30: 117-150. 
Miranda, F. y E. Hernández X. Clasificación de los tipos de vegetación de México aplicable a los levantamientos forestales. Trabajo presentado en Segunda Convención Nacional Forestal en 1959; publicado en mimeógrafo bajo el nombre de "Apuntes de geobotánica, sección bióticos, tipos de vegetación”. 13 pp.

Miranda,-F. \& A. J. Sharp. 1950. Characteristics of the vegetation in certain temperate regions of eastern Mexico. Ecology 31: 313-333.

Nelson, E. W. 1921. Lower California and its natural resources. Mem. Nat. Acad. Sci. 16: 1-194.

Nelson, E. W. \& E. A. Goldman. 1926. Mexico, in: Shelford, V. E., Naturalist's guide to the Americas. Williams \& Wilkins Co. Baltimore. pp. 574-596.

Ochoterena, I. 1918. Las regiones geográfico-botánicas de México. Bol. Soc. Mex. Geogr. Estad. 8: 221-231 (publicado también en forma ligeramente modificada en Rev. Esc. Nac. Prep. 1: 261-331. 1923).

Ochoterena, I. 1937. Esquemas biotípicos y sinecias características de las regiones geográfico-botánicas de México. An. Inst. Biol. Univ. Méx, 8: 463-597.

Ochoterena, I. 1945. Outline of the geographical distribution of plants in Mexico, in: Verdoorn, F., Plants and plant science in Latin America. The Chronica Botanica Co. Waltham, Mass. pp. 261-265.

O'Neill, H. T. 1940. The sedges of the Yucatan Peninsula. Carn. Inst. Wash. Publ. 522: 249-322.

Osorio-Tafall, B. F. 1949. Carta biogeográfica de la República Mexicana, in: Tamayo, J. L., Atlas geográfico general de México. México, D. F.

Purpus, A. P. 1908. Mexikanische Hochgipfel, in: Karsten, G. \& H. Schenck, Vegetationsbilder. 5 Reihe, Heft 8.

Ramírez, J. 1899. La vegetación de México. Oficina Tipográfica de la Secretaría de Fomento. México, D. F. 273 pp.

Ramírez Cantú, D. 1949. Notas generales sobre la vegetación de la Sierra de Tepoztlán, Morelos. An. Inst. Biol. Univ. Méx. 20: 189-228.

Ramírez Laguna, A. 1936. Distribución de los agaves de México. An. Inst. Biol. Univ. Méx. 7: $17-45$.

Reiche, C. 1914. La vegetación de los alrededores de la capital de México. Méxicc, D. F. 145 pp. (publicado también en alemán en forma ligeramente modificada, en Bot. Jahrb. Beiblatt 129. 1923).

Reiche, C. 1924. Consideraciones estadísticas sobre la flora y la vegetación del Valle de México. Méx. Forest. 2: 111-114.

Reinig, W. F. 1937. Die Holarktis. Ein Beitrag zur diluvialen and alluvialen Geschichte der zirkumpolaren Faunen-und Florengebiete. G. Fischer. Jena (citado por Herzfeld, 1956).

Richard A. \& H. Galeotti. 1844. Monographie des orchidées mexicaines, précedée de considérations sur la végétation du Mexique et sur les diverses stations ou croissent les especes d'crchidées mexicaines. Comp. Rend. Acad. Sci. 18: 497-513 (traducido al español en Ramírez, 1899).

Robinson, B. L. 1930a. Observations on the genus Stevia. Contr. Gray Herb. 90: 35-58.

Robinson, B. L. 1930b. The Stevias of North America. Contr. Gray Herb. 90: 90-160.

Rzedowski, G. C. de, 1960. Notas sobre la flora y la vegetación del Estado de San Luis Potosí. VII. Vegetación del Valle de San Luis Potosí. Acta Cient. Potos. 4: 5-118.

Rzedowski, J. 1954. Vegetación del Pedregal de San Angel (Distrito Federal, México). An. Esc. Nac. Cienc. Biol. Méx. 8: 59-129.

Rzedowski, J. 1956. Notas sobre la flora y la vegetación del Estado de San Luis Potosí. III. Vegetación de la región de Guadalcázar. An. Inst. Biol. Univ. Méx. 27: 169-228.

Rzedowski, ฯ. 1957. Vegetación de las partes áridas de los Estados de San Luis Potosí y Zacatecas. Rev. Soc. Mex. Hist. Nat. 18: 49-101.

Rzedowski, T. 1961. Vegetación del Estado de San Luis Potosí. Tesis. Facultad de Ciencias, U.N.A.M. 228 pp. 
Rzedowski, J., El extremo boreal del bosque tropical siempre verde en Norteamérica continental (en prensa).

Sanders, E. M. 1921. The natural regions of Mexico. Geogr. Rev. 11: 212-242.

Schmithüsen, J., 1961. Allgemeine Vegetationsgeographie. Walter de Gruyter \& Co. 2a. edic. Berlin $262 \mathrm{pp}$.

Schornherst, R. O. 1943. Phytogeographic studies of the mosses of northern Florida. Amer. Midl. Nat. 29: 509-532.

Schouw, J. F. 1823. Grundzüge einer allgemeinen Pflanzengeographie. Berlin, (citado por Good, 1953).

Schuchert, C. 1935. Historical geology of the Antillean-Caribbean region. J. Wiley. New York $811 \mathrm{pp}$.

Schuman, K. 1899. Gesamtbeschreibung der Kakteen (Monographia Cactacearum). Verlag von J. Neumann. 2a. edic. Neudamm. 832 pp.

Schwarzbach, H. 1950. Das Klima der Vorzeit. Enke. Stuttgart. (citado por Herzfeld, 1956).

Sharp, A. J. 1945. Notas sobre la flora de la región escarpada del la parte noroeste del Estado de Puebla. Bol. Biol. Univ. Puebla 11/12: 29-32.

Sharp, A. J. 1946a. A preliminary report on some phytogeographical studies in Mexico and Guatemala. Amer. Journ. Bot. 33:844.

Sharp, A. J. 1946b. Informe preliminar sobre algunos estudios fitogeográficos efectuados en México y Guatemala. Rev. Soc. Mex. Hist. Nat. 7: 35-40.

Sharp, A. J. 1948. Some fungi common to the highlands of Mexico and Guatemala and eastern United States. Mycologia 40: 499-502.

Sharp A. J. 1951. The relation of the Eocene Wilcox flora to some modern floras. Evolution 5: $1-5$.

Sharp, A. J. 1953a. Notes on the flora of Mexico: world distribution of the woody discotyle. donous families and the origin of the modern vegetation. Journ. Ecol. 41: 374-380 (publicado también en español en Mem. Congr. Cient. Méx. 6: 343-351. 1953).

Sharp, A. J. 1953b. Generic correlations in the flora of México and eastern Asia. Journ. Tenn. Acad. Sci. 28: 188.

Sharp, A. J. 1961. The asiatic element in the flora of Mexico. Bull. Assoc. Southeastern Biol. $8: 23$.

Sharp, A. J. Algunos aspectos de la fitogeografía de Mexico. Trabajo presentado en el Primer Congreso Mexicano de Botánica (en prensa).

Sharp, A. J., E. Hernández Xolocotzi, H. Crum y W. B. Fox. 1950. Nota florística de una asociación importante del suroeste de Tamaulipas, México. Bol. Soc. Bot. Méx. 11: 1-4.

Shreve, F. 1936. The plant life of the Sonoran Desert. Sci. Mo. 42: 195-213.

Shreve, F. 1937a. Vegetation of the Cape region of Baja California. Madroño 4: 105-113.

Shreve, F. 1937b. Lowland vegetation of Sinaloa. Bull. Torr. Bot. Club 64: 605-613.

Shreve, F. 1942. The desert vegetation of North America. Bot. Rev. 8: 195-246.

Shreve, F. 1951. Vegetation of the Sonoran Desert. Carn. Inst. Wash. Publ. 591. 192 pp.

Smith, A. C. \& I. M. Johnston. 1945. A phytogeographical sketch of Latin America, in "Veráoorn, F., Plants and plant science in Latin America”. The Chronica Botanica Co. Waltham Mass. pp. 11-18.

Smith, H. M. 1940. Las provincias bióticas de México, segúm la distribución geográfica de las lagartijas del género Sceloporus. An. Esc. Nac. Cienc. Biol. Méx. 2: 95-110.

Smith, H. M. 1949. Herpetogeny in Mexico and Guatemala. Ann. Assoc. Amer. Geogr. 39: 219-238.

Smith, L. B. 1940. The Bromeliaceae of the Yucatan Peninsula. Carn. Inst. Wash. Publ. 522: $105-136$.

Standley, P. C. 1916. Comparative notes on the floras of New Mexico and Argentina. Journ. Wash. Acad. Sci. 6: 236-244.

Standley, P. C. 1920-1926. Trees and shrubs of Mexico. Contr. U. S. Nat. Herb. 23: 1-1721.

Standley, P. C. 1928. Flora of the Panama Canal Zone. Contr. U. S. Nat. Herb. 27: 1-416.

Standley, P. C. 1930. Flora of Yucatan. Field Mus. Nat. Hist. Bot. Ser. 3: 157-492. 
Standley, P. C. 1936. Las relaciones geográficas de la flora mexicana. An. Inst. Biol. Univ. Méx. 7: 9-16.

Standley, P. C. 1937. Flora of Costa Rica. Part I. Field Mus. Nat. Hist. Bot. Ser. 18: 1-348. Standley,-P. C. \& S. J. Reccrd. 1936. The forest and flora of British Honduras. Field Mus. Nat. Hist. Bot. Ser. 12: 1-432.

Stecre, W. C. 1935. The mosses of Yucatan. Amer. Journ. Bot. 22: 395-408.

Steyermark, J. A. 1950. Flora of Guatemala. Ecology 31: 368-372.

Swallen, J. R. 1934. The grasses of the Yucatan Peninsula. Carn. Inst. Wash. Publ. 436: 325-355.

Trelease, W. 1918. Bearing of the distribution of the existing flora of Central America and the Antilles on former land connections. Bull. Geol. Soc. Amer. 29: 646-656.

Trelease, W. 1924. The American oaks. Mem. Nat. Acad. Sci. 20: 1-255.

Turner, B. L. 1959. The legumes of Texas. University of Texas Press. Austin, Tex. 284 pp.

Vestal, A. G. 1914. Internal relations of terrestrial associations. Amer. Nat. 48: 413-445.

Vivó, P. A. 1943. Los límites biogeggráficos en América y la zona cultural mesoamericana. Rev. Geogr. 3: 109-131.

Watson, S. 1876. On the flora of Guadalupe Island, Lower California. Proc. Amer. Acad. Arts Sci. n. s. 3: 105.

Watson, S. 1890. The relation of the Mexican flora to that of the United States (abstract). Proc. Amer. Ass. Advanc. Sci. 39: 291-292.

White, S. S. 1948. The vegetation and flora of the region of the Rio de Bavispe in northeastern Sonora, Mexico. Lloydia 11: 229-302.

Wiggins, I. L. 1961. The origins and relationships of the land flora. In: The biogeography of Baja California and adjacent seas. Part III. Terrestrial and fresh-water biotas. Syst. Zool. 9: $148-165$.

Williams, L. O. 1951. The Orchidaceae of Mexico. Ceiba 2: 1-321.

Woodson, R. E., Jr. 1940. The Apccynaceous flora of the Yucatan Peninsula. Carn. Inst. Wash. Publ, 522: 59-102.

Wulff, E. V. 1937. Essay of dividing the world into phytogeographical regions according to the numerical distribution of species. Bull. Appl. Bot. Gen. Plant Breed. Ser. 1, 2: 315-368. 